\title{
THE ACCRETION OF FEDERAL POWER IN LABOR ARBITRATION-THE EXAMPLE OF ARBITRAL DISCOVERY *
}

\author{
EDgar A. JonES, JR.†
}

I

\section{The Changing Role of Arbitration}

Arbitration has existed for centuries in parallel with adjudication ${ }^{1}$ as a method of obtaining a binding decision of a dispute between private citizens. Although arbitral awards had to be enforced through judicial proceedings, the courts would enforce them "when fairly and lawfully made, without hesitation or question," as Justice Story declared in 1845 in Tobey v. County of Bristol. ${ }^{2}$ In the Anglo-American tradition, however, arbitration would not be compelled by the courts; a contractual commitment to arbitrate was not specifically enforceable. "A court of equity," Justice Story said, "ought not to compel a party to submit the decision of his rights to a tribunal, which confessedly does not possess full, adequate, and complete means, within itself, to investigate the merits of the case, and to administer justice." Justice Story

* This is the second of three articles exploring the adaptability of discovery procedures to arbitration in discovery situations occurring during the terms of collective bargaining agreements. The first was Jones, Blind Man's Buff and the NOW-prob-

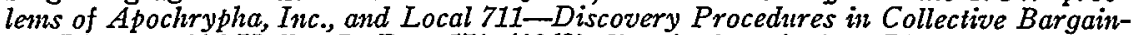
ing Disputes, 116 U. PA. L. REv. 571 (1968) [hereinafter cited as Blind Man's Buff]. The third will appear under the title The Labor Board, the Courts and the Arbitrator -A Feasibility Study of Tribunal Interaction in Grievable Refusals to Disclose. My colleague, William Cohen, gave me helpful criticisms while I was preparing this second of the three articles comprising this study.

Blind Man's Buff indicated the need for an arbitral discovery procedure in the administration of collective bargaining agreements. Arbitral discovery would benefit both unions and employers who are now faced with the prospect of dealing with problems created by refusal to disclose information through the extended procedures of the National Labor Relations Board.

This article will explore the range of policy questions involved in any adaptation of discovery procedures to labor arbitration and will examine various legal doctrines and theories which may be available to effectuate that adaptation.

$\dagger$ Professor of Law, University of California, Los Angeles. A.B. 1942, Wesleyan University. LL.B 1950, University of Virginia. Member, Virginia Bar and National Academy of Arbitrators. See Caveat an Dotsglas, 116 U. PA. L. REV. $571 \mathrm{n}$.* (1968), for my compliance with Mr. Justice Douglas' suggestions in Law Revievs and Full Disclosture, 40 WASH. L. REv. 227, 228 (1965).

$I$ "ADJUDICATION is used of the determination of matters in dispute by the decision of a competent court; ARBITRATron, of the determination of such matters by the decision of arbitrators, whose decision may not be binding until confirmed by a higher court or assented to by the parties." WEBSTER's NEW INTERNATIONAL DICTIONARY 33 (2d ed. unabr. 1950). 1845).

2 Tobey v. County of Bristol, 23 F. Cas. 1313, 1320 (No. 14,065) (C.C. Mass. 
observed that arbitrators at common law could not compel discovery; they had power neither to subpoena nor to administer oaths. ${ }^{3}$ Furthermore, "they are not ordinarily well enough acquainted with the principles of law or equity, to administer either effectually, in complicated cases; and hence it has often been said, that the judgment of arbitrators is but rusticum judicium." 4 Tobey's counsel had argued that "in modern times" most nations not only favored arbitration but often made it compulsory. Not so, said Justice Story; when made compulsory "it is by legislative authority, which at the same time, arms the arbitrators with the fullest powers to ascertain the facts, to compel the attendance of witnesses, to require discovery of papers, books and accounts, and generally, also, to compel the parties to submit themselves to examination under oath." 5 Even then, "so far as the system of compulsive arbitrations has been tried in America, the experiment has not, as I understand, been such as to make a favorable impression upon the public mind, as to its utility or convenience. At all events, it cannot be correctly said, that public policy, in our age, generally favors or encourages arbitrations which are to be final and conclusive, to an extent beyond that which belongs to the ordinary operations of the common law." 6

$3 I d$. at 1320.

4 Id. at 1321.

5 Id. The Justice added that "arbitrations are never, or at least not ordinarily, made compulsive to the extent of excluding the jurisdiction of the regular courts of justice. ..." Id. He saw them as "mere preliminaries" to appeals to the courts in which the law and the facts would be re-examinable.

BId. Even were it so, he reasoned, and the ground of the existing doctrine were felt to be "not solid or satisfactory," a judge "must content himself upon this, as many other occasions, to administer the established law, and walk in the footsteps of his predecessors, super antiquas vias." Id. at 1320.

Poor Tobey! If ever there was an antiqua via, it was his Plymouth-Bristol road. He contracted with the commissioners of Bristol county on January 1, 1828, to build it. He also undertook to procure the location of that part of the overall route which lay in Plymouth county. There was to be "a new and more eligible avenue from Taunton to New Bedford." But the Bristol county commissioners, contrary to their contractual commitment, failed to record the legal location of their road, "the same was illegal, and your petitioner was put to great expense and delay to procure the legal location of the said road in Plymouth county, and the working of the same." So the Bristol commissioners and Tobey "mutually waived" the original contract and the commissioners promised to indemnify him for the additional expenses caused him by their oversight. He went on with the roadbuilding, therefore, and it was accepted by the county in June, 1830. It had since been "a very useful one for the county." Id. at 1315. But the commissioners again defaulted and Tobey had to go to law. But he only got partial recompense. He then turned to arbitration by successfully petitioning the Massachusetts legislature to adopt a resolution in 1839 (eleven years after starting the road, nine after its completion), $i d$. at 1316, authorizing the commissioners to submit the matter of his recompense to arbitration. Still the commissioners, consenting to arbitrate some of the claims on November 22,1842 , nonetheless refused to submit those of his claims they deemed unfair and unjust. So in the May term, 1845, of the federal circuit court sitting in Massachusetts, Tobey sought through a bill in equity to compel the commissioners to submit the dispute to arbitration as authorized in the legislature's resolution of 1839 . Tobey finally had come to the end of the road after those 17 persistent years, only to find that his way was blocked by Mr. Justice Story's own equally persistent but more compelling antiqua via. 
A century later, by the end of World War II, Justice Story's basic public policy premise had been reversed. Arbitration had been effectively converted to the uses of a wartime economy searching for industrial stability, and was about to enter a decade of considerable growth. Thousands of labor disputes arising under collective bargaining agreements were to be resolved through the decisions of several hundred arbitrators and with no involvement of the courts. ${ }^{7}$

This evolution was accelerated in 1957 by the Supreme Court in Textile Workers v. Lincoln Mills, ${ }^{8}$ where the Court concluded that Congress, in the Taft-Hartley Act of 1947, had "adopted a policy which placed sanctions behind agreements to arbitrate grievance disputes," ${ }^{\circ}$ thereby laying the statutory foundation which Justice Story believed to be necessary. The Court, in a judicial tour de force of striking dimensions, declared that:

[T] he substantive law to apply in suits under $\S 301$ (a) is federal law, which the courts must fashion from the policy of our national labor laws. . . . The Labor Management Relations Act expressly furnishes some substantive law. It points out what the parties may or may not do in certain situations. Other problems will lie in the penumbra of express statutory mandates. Some will lack express statutory sanction but will be solved by looking at the policy of the legislation and fashioning a remedy that will effectuate that policy. The range of judicial inventiveness will be determined by the nature of the problem. ${ }^{10}$

The Court also pointed to state law as a possible resource of policy. But it decreed that any state law utilized will be absorbed and become federal law and "will not be an independent source of private rights." 11

Despite the rapid growth of arbitration as an effective means of settling labor disputes, the procedural deficiencies inhibiting factdiscovery by arbitration, which were underscored by Mr. Justice

7 For an historical summary of the development of arbitration, see Jones, Power and Prudence in the Arbitration of Labor Disputes: $A$ Venture in Some Hypotheses, 11 U.C.L.A. L. REv. 675, 701-09 (1964) [hereinafter cited as Jones, Pozver and Prudence].

8353 U.S. 448 (1957).

$9 I d$. at 456 .

10 Id. at 456-57. The Court later broadened its summons to encompass state judges so that they could act concurrently. Teamsters Local 174 v. Lucas Flour Co., 369 U.S. 95 (1962); Charles Dowd Box Co. v. Courtney, 368 U.S. 502 (1962). It has been said that Lincoln Mills set a new direction "pregnant with possibilities" not only for arbitration and collective bargaining, but also for relations between the federal and state governments, the Supreme Court and Congress, and ultimately perhaps, even between citizens and the courts. Friendly, In Praise of Erie-and of the New Federal Common Law, 19 RECond of N.Y.C.B.A. 64, 85 (1964); see Jones, Jurisdictional Dispute Arbitration; The Jostling Professors-For the Respondent, 14 U.C.L.A. L. REV. 351 (1966).

11353 U.S. at 457. 
Story, ${ }^{12}$ remain unresolved. Even though current public policy favors voluntary arbitration of labor disputes, we still continue, in large measure, to adhere to outmoded assumptions regarding the power of arbitrators to fashion discovery procedures. These assumptions are, first, that arbitrators do not have discovery powers unless they are expressly provided for either by the collective bargaining agreement or by state statute; and second, that arbitrators in general, for reasons almost universally unstated, ought not in any event to be empowered to administer discovery procedures. ${ }^{13}$

Today those older assumptions no longer retain their validity with respect to labor arbitration. The evolution of labor-management collective bargaining ${ }^{14}$ has been stimulated and sustained by responses to pragmatic rather than theoretical considerations. The current development of modes of resolution of labor disputes reflects a significant and complex redistribution of decision-making power among federal and state courts, the National Labor Relations Board and privately selected arbitrators. This tribunal interaction directly affects the resolution of those disputes which occur during the terms of approximately 125,000 existing collective bargaining agreements (of which perhaps 95 per cent have arbitration provisions) involving a third or so of the nation's work force. ${ }^{15}$ The stimulus for this redistribution of decision-making power is federal; in execution, it is a judicial rather than a legislative phenomenon. And its tendency is to rely less on statutory criteria and more on contractual standards bargained out prior to a specific dispute by management and the union, each in pursuit of its own views of its economic and philosophical interests which are at once personal, constituent and institutional.

The logic of this evolution commits jurisdiction over most (but by no means all) of the first-instance labor disputes arising in the course of collective agreements to jointly created and staffed "private" arbitration tribunals. ${ }^{16}$ A relatively small number of first-instance problems are reserved by operation of law (irrespective of the wishes 1845).

12 Tobey v. County of Bristol, 23 F. Cas. 1313, 1320 (No. 14,065) (C.C. Mass.

13 See generally Blind Man's Buff 576 n.6.

${ }^{14}$ See generally C. Gregory, LABOR AND tHe LAW 29 (2d ed. rev. 1958).

15 See U.S. Bureau of IaAbor Statistics, Dep't of Labor, Buli. No. 1425-1, Major Collective Bargaining Agreements-Grievance Procedures (1964). See also U.S. Bureau of Labor Statistics, Dep'T OF LABOR, BULL. No. 1425-6, ArbitraTION Procedures (1966).

16 It is something of a misnomer to categorize labor arbitration today as a "private tribunal." See Jones, Power and Prudence 741. And see my forthcoming paper delivered at and to be published in the proceedings of the Fourteenth Annual Institute on Labor Law of the Southwestern Legal Foundation: The Schizophrenic World of Labor Arbitration and Mr. Q. Vadis, Arbitrator (1968). 
of the bargainers) for initial decision by the Board or by the courts. ${ }^{17}$ Aside from legal concepts, the vast bulk of contract disputes is resolved by the parties through the operation of their grievance procedures terminating in arbitration, with no recourse to the courts or the Board. At least 10,000 arbitral decisions issue each year, in contrast to about 150 to 200 judicial decisions and about two dozen Board orders disposing of contractual issues which could otherwise be arbitrated. As to other problems, there is considerable overlap in the responsibility of the various tribunals, although there is now a tendency to evolve a predetermined sequence of tribunal interaction..$^{18}$

With these developments in the background, we may now examine the various policy questions involved in the adaptation of discovery procedures to the arbitral process, and the incorporation of these procedures into the evolving Board-court-arbitration system for the resolution of labor disputes occurring during the terms of collective bargaining agreements. Broadly speaking, those policies may be said to comprise two sets of concerns: first, those primarily economic in nature, radiating from the nature of the institution of collective bargaining and the expectations of its future; and second, those which are legal, concerning regulation of economic activities, judicial administration and rights of the individual. We turn now to the economic considerations involved in an arbitral discovery remedy.

II

\section{Economic Aspects of Arbitral Discovery}

Reactions to the prospect of arbitral discovery raise concerns about the nature and growth of the labor arbitral process. These concerns

17 Some of these problems cannot be resolved jointly by the parties because their bargaining relationship has so seriously deteriorated as to require governmental intervention. For example, there may be refusals to disclose information needed to administer the collective agreement, a violation of sections 8(a) (5), 29 U.S.C. $\S 158$ (a) (5) (1964), and 8(b) (3), 29 U.S.C. §158(b) (3) (1964), of the National Labor Relations Act, which may warrant treatment as a statutory, rather than as a contractual, problem when the issue is presented to the Labor Board. The Board is empowered to make that choice. NLRB v. Acme Indus. Corp., 385 U.S. 423 (1967). Other problems may involve the interests of persons not parties to the agreement when these interests cannot fairly be disposed of without their participation. But arbitral techniques are being evolved in response to some of them. See, e.g., Dannett, Arbitration of Jurisdictional and Representational Disputes, N.Y.U. 20Te ANN. CONF OF LABOR (1967); Jones, $A$ Sequel in the Evolution of the Trilateral Arbitration of Jurisdictional Labor Disputes-The Supreme Court's Gift to Embattled Employers, 15 U.C.L.A. L. Rev. No. 3 (April, 1968); Jones, An Arbitral Answer to a Judicial Dilemma: The Carey Decision and Trilateral Arbitration of Jurisdictional Dispntes, 11 U.C.L.A. L. Rev. 327 (1964). Compare Stardust Hotel, $50 \mathrm{Lab}$. Arb. - (1968) (E. Jones, Arbitrator), with Maier Brewing Co., 45 Lab. Arb. 1115 (1966) (E. Jones, Arbitrator). Sometimes a private solution will contravene a preemptive public policy. See, e.g., Syres v. Oil Workers Union, 350 U.S. 892 (1956) (per curiam), reversing 223 F.2d 739 (5th Cir. 1955).

18 For example, it is the avowed policy of the Labor Board to defer to an existent arbitration procedure in "appropriate circumstances." See 31 NLRB ANN. REP. 43 (1966). 
principally focus on (A) the impact on the quality of collective bargaining, its arbitral process, and the changing expectations of the roles properly assignable to arbitration in the structure of national labor policy; (B) the manifest trend toward greater complexity in the fulfillment of those roles; (C) the erosion of consensuality as the sole foundation of labor arbitration; (D) the potential for abuse of discovery procedures; and $(E)$ the "institutional competence" of the arbitrator relative to the administration of discovery in the setting of collective bargaining.

\section{A. The Impact of Discovery on Collective Bargaining}

\section{The Intent of the Parties}

It has recently been stated that "discovery is generally not available as an incident of the arbitration proceeding itself" because it is "inconsistent with the desires of parties who refer their disputes to arbitrators rather than to formal judicial tribunals." 19 The reason given for withholding access to judicial discovery in an arbitral proceeding is that the parties to an arbitration agreement have expressed their preference for an informal, expedited, and less costly method of dispute-resolution than is available through judicial proceedings. To thrust upon one of them the judicial apparatus of discovery, it is felt, is to deny to that party the anticipated incidents of his bargain.

But this summary dismissal of the prospect of discovery in arbitration is founded on certain untenable assumptions. Essentially, these assumptions beg the following questions:

(a) Have the parties, by executing an arbitration agreement containing no reference to discovery procedures, necessarily demonstrated their intent never to be compelled to make disclosure through discovery in connection with disputes arising under the agreement?

(b) During negotiations, were there situations foreseeable from which an inference might reasonably be drawn that they contemplated an obligation of disclosure?

19 Developments in the Law-Discovery, 74 HARv. L. REv. 940, 943 (1966). Commercial Solvents Corp. v. Louisiana Liquid Fertilizer Co., 20 F.R.D. 359 (S.D.N.Y. 1957), is often cited for the proposition that arbitral discovery is not only unavailable, but also deserves to be characterized as superfiuous and incompatible. Id. at 362 . The court there noted that "by voluntarily becoming a party to a contract in which arbitration was the agreed mode for settling disputes thereunder respondent chose to avail itself of procedures peculiar to the arbitral process rather than those used in judicial determinations." Id. at 361. Judge Learned Hand articulated a common conception of arbitration when he said of parties to an arbitration agreement:

they must be content with its informalities; they may not hedge it about with those procedural limitations which it is precisely its purpose to avoid. They must content themselves with looser approximations to the enforcement of their rights than those that the law accords them. ...

American Almond Prods. Co. v. Consolidated Pecan Sales Co., 144 F.2d 448, 451 (2d Cir. 1944). 
(c) Are there contractual provisions, aside from the arbitration provision, which lead to the conclusion that disclosure is an enforceable contractual commitment?

(d) Are there obligations of disclosure imposed by law which warrant the conclusion that they are implicitly integrated as contractual commitments?

None of those questions can be summarily answered either to affirm or to deny arbitral discovery. The answers must be determined in light of the necessities of an effective labor arbitral process and of the reasonably deducible intent of the parties to a particular collective agreement.

It is obvious that a major purpose of the usual multi-step grievance procedure is to achieve the earliest possible disclosure of the operative facts of the dispute and the dispositive contractual 'provisions. It is in the pressing self-interest of each party, for many reasonspsychological, political and economic - to get the dispute resolved as soon as possible. The passage of time sparks unresolved grievances into begetting new ones; it causes irresolution among supervisors and employees concerning how they ought to operate, mutual distrust, a reluctance to "get on with it" at the job lest the "rights" of either somehow be jeopardized, and a hardening of compromise attitudes; and it generates suspicions of motives. Neither party to a collective agreement in a normal bargaining situation benefits from uncertainty in the operation of the grievance procedure, and both parties realize it. To that strong impetus to disclosure is linked the joint intent to submit the few unresolvable disputes to an arbitrator they jointly select.

Disclosure is thus a normal characteristic of a properly functioning grievance procedure. The grievance procedure establishes a routine expectation among workers and supervisors that if someone has a "gripe" about job performance or working conditions he is supposed to "get it off his chest." Were it otherwise, it is recognized, disputes would fester and infect the working relationships in the bargaining unit. This operates to the economic and psychological detriment of the employees, the employer and the union. The whole thrust of the grievance procedure is toward early and complete disclosure so that settlement can ensue. Therefore, the existence of a grievance procedure, capped by an arbitration agreement, strongly implies a contractual obligation to disclose. The parties will normally have directed their arbitrator to abide by and not "alter, amend or modify" their contract. In order to fulfill this mandate and formulate a sound interpretation of contractual intent, the arbitrator must have access to the stuff and substance of their disputes. If one party withholds informa- 
tion needed in order to present the arbitrator with as complete a view of the dispute as possible, that refusal to disclose is incompatible with the decisional responsibility imposed on the arbitrator by both parties. ${ }^{20}$

Furthermore, the Supreme Court in Acme Industrial has observed that the grievance procedure performs an indispensable winnowing function:

Arbitration can function properly only if the grievance procedures leading to it can sift out unmeritorious claims. For if all claims originally initiated as grievances had to be processed through to arbitration, the system would be woefully overburdened. ${ }^{21}$

In addition to the parties' contractual intent to effectuate disclosure through their grievance procedure, national labor policy requires it of them-and they bargain under its aegis. Employers and unions, under sections $8(\mathrm{a})(5),{ }^{22} 8(\mathrm{~b})(3),{ }^{23}$ and $8(\mathrm{~d}),{ }^{24}$ are required to bargain in good faith. This obligation includes disclosure of data relevant to their negotiations about wages, hours and conditions of employment. Information necessary to the proper functioning of the grievance procedure must be disclosed under that statutory duty to bargain. ${ }^{25} \mathrm{Al}$ though the Labor Board seems almost exclusively to have been dealing with employer refusals, ${ }^{26}$ there is no doubt that unions are required to disclose when circumstances warrant an employer's inquiry. It is elementary contract law that the parties are routinely deemed to enter into their collective agreement with the intention to abide by the obligations imposed upon them by law.

Further evidence of an implicit disclosure-intent is the fact that the absence of arbitral discovery preserves the outmoded "sporting theory of justice" in the collective bargaining process. This kind of legal gamesmanship has been eliminated in the courts by adoption of modern discovery rules, exemplified by the Federal Rules of Civil

20 Of course, the parties can expressly confer or withhold authority from the arbitrator to administer discovery. The real problems naturally arise when the agreement is silent on the subject. If it explicitly or implicitly empowers the arbitrator to use discovery techniques, the legal procedures to enforce his award will be found in federal law if the dispute involves interstate commerce. See note 200 infra.

21385 U.S. at 438.

22 National Labor Relations Act $\$ 8(a)(5), 29$ U.S.C. $\$ 158(a)$ (5) (1964) [hereinafter cited as NLRA].

23 Labor Management Relations Act (Taft-Hartley Act) §8(b) (3), 29 U.S.C. $\$ 158$ (b) (3) (1964) [hereinafter cited as LMRA].

24 LMRA § 8(d), 29 U.S.C. \$158(d) (1964).

25 See NLRB v. Acme Indus. Co., 385 U.S. 432, 435-36 (1967).

26 No union refusal-to-disclose case was found in which the Board issued an order to a union to disclose. See, however, Discovery Situation \#1, in Blind Man's Buff 558, detailing the facts of Associated Home Builders v. NLRB, 352 F.2d 745 (9th Cir. 1965). 
Procedure, but remains quite visible in the arbitration of labor disputes. When calculated nondisclosure or surprise disclosure succeeds in frustrating the prosecution or defense of an arbitral grievance, collective bargaining has been injured. This manuever is incapable of satisfactory justification to those employees, unions or employers who should prevail on the merits, but who have been bilked by tactical artifice.

We may conclude, therefore, that disclosure through the grievance procedure is the deducible intent of the parties when their agreement is silent on the subject of arbitral discovery. The arbitrator who issues an arbitral discovery order in appropriate circumstances is functioning within the ambit of their interest.

\section{The Compatibility of Discovery With Bargaining}

An identifiable concern over the prospect of discovery is whether its use might unduly stimulate an adversary atmosphere inimical to the continuing relationship of the bargaining parties. It might be thought enough of a response to that concern simply to observe that "adversariness" already exists where there is, on one side, an insistent demand for disclosure and, on the other, an adamant refusal to disclose. But the question expresses a deeper concern based on the marked characteristic of continuity unique to American collective bargaining: so many employers and unions accept their bargaining relationship as going on indefinitely.

Yet collective bargaining confronts an employer with officials of a union who are the elected and certified representatives of his employees. The officials are elected by secret ballot. Their political life, possibly the continued institutional existence of the union and certainly its continued status as bargaining representative for this group of employees, require that they engage in adversary bargaining on behalf of their constituents. Their goal is to elicit the most favorable wages, hours and conditions that can be gained from the employer. The bargaining table in the American tradition is a tug-and-haul arena in which forbearance for the common good is rare. But even where a joint effort is made to gear worker appetite for income to employer capacity to satisfy it, the atmosphere typically can only be regarded as adversary. This is not necessarily invidious. The legal system on which we base our expectations of due process relies on conflicting pursuits of self-interest, through the efforts of representatives experienced in the arts of advocacy, to produce a binding resolution of the dispute. We accept that result as the "justice" of the case. But we recognize that this is an acceptance which may not conform to the 
conclusion of some enlightened philosopher who is somehow informed of all the available subjective and objective elements caught up in the particular human situation. The truth is that there is a marked similarity between the Anglo-American adversary system of justice and the socio-economic institution we call collective bargaining. It is difficult to see how arbitral discovery, prudently administered, would either trigger or accentuate combative impulses not already harnessed to the task of negotiations between unions and employers.

Arbitration, however, is not a process which can put back together a bargaining relationship that has come unstuck. In that context, it is useless to embroil the arbitrator in the bitter atmosphere of a fractured relationship in which any remedy he may fashion will be foredoomed to failure. Rather than arbitration, economic self-help and litigation, whether in court or before an administrative agency, constitute the primary means for the resolution of disputes in such situations.

But tough bargaining, including resort by a union to a lawfully conducted economic strike, is a common occurrence in American industrial relations, and it is crucial to recognize that this does not necessarily evidence a fractured relationship. Non-strike collective bargaining often seems preferable for all concerned, but it remains true in our economy that unions often need to counter economic pressures of employers by the ultimate economic pressure device at their commandthe withholding of their labor. Strikes are an aspect of bargaining, not its antithesis.

Similarly, an employer's or a union's refusal to disclose information during the term of a collective agreement should not alone be considered unlawful. It does not necessarily evidence bad-faith bargaining. Far more often than not, it is merely a symptom of hard-headed bargaining, a reality which the Board often fails to grasp. Thus it makes far more sense to put an expedited disclosure remedy within the control of the parties to the agreement than it does to impale them for years upon a Board proceeding which, at best, would ultimately result in an abstract vindication of the statutory right to disclosure. We are concerned in discovery situations with reinforcing a sound bargaining relationship; we ought to be receptive to whatever system compresses time, remains close to the control of the parties, eliminates the need for governmental intrusion, and effectively requires appropriate disclosures.

The Board's statutory structure effectively vitiates its usefulness as a viable discovery mechanism. As we shall see in the third article in this series, it takes the Board an average of 17 months to issue a disclosure order. In the 49 per cent of the Board's disclosure orders 
requiring federal court enforcement, an average of more than 29 months elapses between the demand for disclosure and the court's enforcement of the order. There are types of grievances in which that kind of delay in disclosure removes any prospect of adequate relief for contractual wrongs. Some examples are employee discharges, union no-strike violations, bargaining-unit work assignments, discriminations against employers, and subcontracting disputes. ${ }^{27}$

\section{The Element of Compulsion}

Viewing arbitration as a consensual process, exclusive of elements of compulsion, some would be apt to reject the prospect of arbitral discovery on the ground that the introduction of any element of compulsion in the bargaining relationship should only be the result of negotiations. ${ }^{28}$ They would argue that since discovery relies on compulsion to cause information to be disgorged by someone unwilling to disclose, and since techniques involving unilaterally invoked compulsion are incompatible with the basic premise of consent, only techniques which have been bilaterally negotiated should be utilized in labor arbitration. The role of consensuality has been somewhat exaggerated in discussions of labor arbitration. It is undoubtedly true that we place consensuality very high in our order of values. But we have had little hesitancy over the years in fashioning remedies, when we feel they are needed, which blend compulsion with consensual elements to achieve a workable balance. Nor has the Supreme Court been deterred by this conceptual problem. In 1964, in John Wiley \& Sons v. Livingston, ${ }^{29}$ the Court observed that the central reality of "the peculiar status and function of a collective bargaining agreement is the fact . . . that it is not in any real sense the simple product of a consensual relationship." 30 Again, in 1966, Justice Black (himself a close critic of the judicial doctrines governing the labor arbitral process) emphasized for the Court in Transportation-Communication Employees Union v. Union Pacific Railroad ${ }^{31}$ the marked differences between mercantile contracts and the collective bargaining agreement. The latter "is not an ordinary contract for the purchase of goods and services, nor is it governed by the same old common-law concepts, which control such

27 See generally the discussion in Blind Man's Buff 602-04.

28 Compare Bernstein, Nudging and Shoving All Parties to a Jurisdictional Dispute Into Arbitration: The Dubious Procedure of National Steel, 78 HARv. L. Rev. 784 (1965), with Jones, On Nudging and Shoving the National Steel Arbitration Into a Dubious Procedure, 79 HARv. L. REv. 327 (1965).

29376 U.S. 543 (1964).

$30 \mathrm{Id}$. at 550 .

31385 U.S. 157 (1966). 
private contracts." 32 Yet one can preserve a working preference for consensuality without feeling obligated to reject useful arbitral techniques simply because they may be thought to be tainted with strains of compulsion.

Discovery has for centuries been accepted by the courts as an allowable instrument of justice despite its manifest elements of compulsion. But in the context of collective bargaining, as we have seen, consensual elements do exist which point persuasively to a contractual commitment to disclose. Such consensual elements support an arbitral discovery remedy.

\section{The Concern About "Legalistic" Complexity}

Labor arbitration became visibly more complex in the decade from 1957 to 1967, particularly in its interactions with courts and the Labor Board. This development is a matter of concern to many. Arbitral discovery would manifestly be another step in that "deplored" direction. Some would argue that what is needed instead is a reversal of the trend so that arbitrators may, as before, deal directly with the parties without concern for the interposition of "outside" policies or tribunals, Would recognition of an arbitral discovery remedy result in burdening the grievance procedure with unwanted and unneeded formalism, legalism and complexity?

Although resistance to further complexity is warranted, it is also necessary to react to demonstrated need. The inquiry should be aimed at that demonstration rather than smothered by abstract concerns about "legalism." As we have seen in Blind Man's Buff," a real need exists. The need, then, is to design an arbitral discovery remedy which will avoid the evils of undue complexity.

Perhaps the principal concern about injecting "legalistic" procedure into arbitration in this instance is that discovery might prove too elaborate and time-consuming for this informal process, which must handle "small" as well as "big" cases in an expedited and inexpensive manner. The typical labor arbitration hearing is brief. Furthermore, Robben Fleming has demonstrated that there has been little change in the number of hearing days consumed in arbitration in the 1951-1963 period. $^{34}$ Confirmed by an independent Federal Mediation and Conciliation Service tabulation of all cases in its files for 1962 (the average being 1.15 days), his research for selected periods (1951-52, 1956-57, 1962-63), limited to discharge cases, disclosed one-day hearings to be 
overwhelmingly typical. Of a 98-case sample in the 1962-63 period he found that about 82 were concluded in no more than one full day, some taking less than a full day.

Fleming's data confirm the impression drawn from experience that it is only in a rare situation that an arbitrator finds it necessary to recess the hearing because of what courts would regard as pre-trial problems. It is quite common for an arbitrator to suggest, in the course of the morning, what we might call, rhetorically, "lunchbreak discovery": "Why don't you dig that out during the lunchbreak and make it available?" The parties general comply and disclosure is routine when the hearing resumes after luncheon.

These facts should put to rest the concern that discovery is too elaborate a process to be used in an arbitration in which the stakes are not substantial. Quite aside from the fact that the grievant is always likely to see the outcome as important, the "small" case already committed to arbitration may well benefit, at least as much as the "big" case, from resort to discovery. Mr. Justice Brennan, reflecting on his extensive state and federal judicial experience, has observed that pretrial procedures are perhaps even more needed in the small than in the big case, because of their effectiveness in putting "people in a frame of mind to settle." 35

As that suggests, even the prospect of discovery may help resolve the "small" case. Beyond that, there is also a built-in regulator in that kind of case which discourages undue resort to discovery. The reaction of the opposite party must be calculated. Is he apt to retaliate in kind? If so, cost could escalate, and, in turn, the adversary may get a look behind the initiator's tactical facade. This possibility might well lead either a union or an employer to back off from a discovery situation. But where there is an abiding sense of having been contractually wronged, or a lingering fear that substantial rights may be in jeopardy due to imperfectly understood or uncertainly perceived actions by the other party to the collective agreement, there is often a pressing need for resolution. Simple discovery techniques can be applied to effectuate that resolution without making a "federal case" out of each request for discovery. Since the efficient operation of the grievance procedure requires fair disposition of each case, and since neither party will normally escalate a "small" case into a "big" one by unwarranted resort to discovery, it makes no sense to oppose arbitral discovery because of some notion of a distinction between "big" and "small" cases.

35 Brennan, Introduction to the Problem of the Protracted Case, 23 F.R.D. 376, 379 (1958). 


\section{The Expense of Arbitral Discovery}

On the other hand, whether the case be "big" or "small," undoubtedly a major concern at the prospect of arbitral discovery is that of the expense thought to be involved. Expense has been invoked as the major element in deducing an intent to reject discovery among parties to commercial arbitrations. In addition, there is the national policy, strongly emphasized in the Federal Rules of Civil Procedure, to minimize the costs of litigation. But the danger of significantly increased expense due to use of arbitral discovery in a labor case is not a real one. This is so for two reasons.

First, most employers and unions who become involved in NLRB refusal-to-disclose proceedings elect to participate as intervenors, a choice which is more costly than resort to arbitral discovery would normally be. This means that seeking disclosure through a Board proceeding will not necessarily be inexpensive for a union or an employer as the charging party.

Second, the costs of arbitral discovery would not in fact be great. The Speck study of federal practice found that discovery costs about $\$ 300$ in the ordinary tort action in which oral depositions were taken. This involved four or five hours, four or five witnesses, and some 150 pages of transcript at a total cost of about $\$ 100$ for the reporter and $\$ 200$ for the attorney. ${ }^{36}$

At about the same time, in 1951-52, a more broadly based University of Minnesota study surveyed lawyers in twenty-five jurisdictions where discovery was commonplace and in three where it was unknown in the state practice. ${ }^{37}$ Oral questioning was much preferred (92 out of 97 respondents) to written interrogatories. The replies also indicated that lawyers were hardly harassing their adversaries with barrages of depositions; 2.166 was the average number per case, "for the obvious reason that in the small case so many depositions are neither needed nor economically feasible." 38 Although Federal Rule 29 allows the use of an office stenographer by stipulation of the parties, only 2 out of 95 did so; the others used commercial or court reporters. ${ }^{39}$ The cost of doing so might appear surprisingly low, relative to Speck's 1948-50 figures, until it is realized that Speck really hypothesized five witnesses at five hours to arrive at 150 pages and $\$ 100$. On the other

${ }^{36}$ Speck, The Use of Discovery in United States District Conrts, 60 Y ALE L.J. 1132, 1150 (1951).

37 Wright, Wegner \& Richardson, The Practicing Attorney's View of the Utility of Discovery, 12 F.R.D. 97 (1951).

$38 \mathrm{Id}$. at 100 .

$39 I d$. 
hand, the Minnesota study showed that usually one or two witnesses are examined at an average transcript cost of $\$ 30.87 .^{40}$

That 1952 cost compares roughly with a 1967 figure from California, where reporters' fees are regulated by statute, ${ }^{41}$ of about $\$ 82.50$, assuming two witnesses whose testimony is contained in 60 pages (Speck's apparent measure and the likely Minnesota study average) with an original and one copy being produced. An added copy would mean an additional $\$ 22.50 .{ }^{42}$ The authors of the Minnesota study concluded from their correspondence that "other than the cost of the transcription itself, the expenses of discovery are negligible." ${ }^{43}$ Of course, they were also referring to oral depositions, not interrogatories. The average time spent in the course of taking the deposition was about an hour and three-quarters, and the attorneys averaged about an hour and a half analyzing the results. ${ }^{44}$ Counting all expenses involved, the average total cost to the discoverer was $\$ 56.63$, and to the adverse party $\$ 27.47 .45$ Finally, 99 out of 101 respondent attorneys felt "the value of discovery to be commensurate with the expense." 46 That acceptance of discovery was accompanied mostly by enthusiastic endorsement. One partner in a large Chicago law firm commented, "I believe discovery by deposition to be the most valuable tool placed in the hands of trial counsel in the last half century." 47

In labor grievance cases, arbitral discovery by deposition would usually not involve more than one witness, perhaps two on occasion, but rarely more. Using the 1967 California fees as a projection, and accepting 30 pages as a good rough estimate for recording the examination of one witness, would mean a deposition cost of about $\$ 41.25$, hardly an extravagant sum. To that expense would have to be added attorneys' fees. The Minnesota study found attorneys' deposition fees ranged from $\$ 10$ to $\$ 100$. Whether there would be much resort to deposition-discovery is questionable. It seems much more likely that arbitral discovery would be used to elicit statements of position or intent in documentary form, although through inquiries not framed as elaborately as the usual interrogatory and often by an employer or union representative without legal advice. The informality which characterizes so many arbitral hearings may be expected to carry over to the administration of arbitral discovery, with a consequent diminution of expense.

$40 I d$. at 101.

41 CAL. GOV'T CODE $\$ 8211$ (1967).

42 Id.

43 Wright, Wegner \& Richardson, supra note 37, at 101.

44 Id. at 102 .

45 Id.

46 Id. at 103 .

47 Id. at 105 . 


\section{The Cost of Letting the Board Get the Data}

Another aspect of concern for expense, of course, is the mistaken notion that disclosure through a Board proceeding will not be expensive. When an aggrieved party, however honestly, charges a contractually and statutorily wrongful refusal to disclose, that party will normally not be willing to remain aloof while the NLRB pursues relief for it. Although not a disclosure case, $U A W$ v. Scofield ${ }^{48}$ is illustrative of the practice of intervention. There, the Supreme Court was asked to decide whether the prevailing party in a Labor Board proceeding had the right to intervene in the enforcement proceedings in the court of appeals. The Labor Board had dismissed charges against a UAW local for fining certain members for exceeding incentive pay ceilings set by the union. The individual employees sought review in the Seventh Circuit. The union moved to intervene in that proceeding, on the ground that it would be directly affected were the court to set aside the Board order and direct entry of a remedial order. The Supreme Court, reversing denial of the motion, established the right of intervention.

In the course of its opinion, the Court observed that permitting intervention "insures fairness to the would-be intervenor." ${ }^{49}$ It is true that denial of intervention would leave the denied party free and clear of technical res judicata rules. But the Court recognized that the realities give no great solace to a party vitally interested in the substance of the proceeding yet unable to affect the assembly and presentation of the stuff of decision to a tribunal which "has not crystallized its views." 50

For precisely this reason, the Labor Board's procedures permit the filing party to participate in the hearing with formal recognition. ${ }^{51}$ In that capacity, he may call and cross-examine witnesses; file exceptions to any order of the trial examiner; file a petition for reconsideration of a Board order; obtain review as an aggrieved person of Board dismissal of the complaint; and now, in the reviewing court, he may participate in designating the record, in pre-hearing conferences for simplification of the issues; in the filing of briefs; in oral argu-

48382 U.S. 205 (1965).

$49 \mathrm{Id}$. at 213.

$50 \mathrm{Id}$.

51 NLRB Rules and Regulations and Statements of Procedure, 29 C.F.R. \$102.8 (1965): "The term 'party' as used herein shall mean ... any person filing a charge or petition under the act, any person named ... as party to a contract in any proceeding under the act." For an analysis of the rights of a charging party before the Board, see Comment, The Charging Party Before the NLRB: A Private Right in the Public Interest, 32 U. CHI. L. REv. 786 (1965). 
ments; and in petitioning the appellate court for rehearing or in petitioning the Supreme Court for certiorari.

The Supreme Court saw significant public benefit in this participation by an affected employee, employer or union as a "party" in defining the issues and bringing all relevant material to the attention of the Labor Board and the appellate court. ${ }^{52}$ In addition, there is the important judicial-administrative fact that "party" participation is conducive to the "winnowing process" which results in over ninety-seven per cent of unfair labor practice charges being resolved before the circuit court has entered a decree..$^{53}$

Persons affected by an unfair labor practice commonly claim that they have vital private rights in the Board proceedings, which require representation by someone conversant with Board procedures and doctrines; of course, such representation inevitably means litigation expense. Very few unions or employers are apt to feel that they can stand aloof from Board proceedings in order to save money. If the actions involved are serious enough to warrant issuance of an unfair labor practice complaint by the General Counsel, it is recognized to be false economy indeed not to insure that the tribunal has all of the relevant data and insights which can be marshalled. Thus, it is illusory to think that one can avoid expense by relying on the federal government to bear the financial burden of effecting discovery through a Labor Board order, even in the unlikely event that the extended timespan involved in the Board-court proceeding is not of critical concern.

\section{The Prospects of Abuse}

Undoubtedly a major concern about the adaptation of discovery to arbitration is that arbitral discovery might be subject to a considerable amount of abuse. Litigation costs have always provided a potential for abuse of legal procedures. For example, it is said that discovery has been used on occasion by litigants, not really to prepare for trial,

52382 U.S. at 215 . Substantially the same kind of reasoning supports trilateral arbitration of interunion jurisdictional disputes occurring during the term of one or more collective agreements. See Jones, $A$ Sequel in the Evolution of the Trilateral Arbitration of Jurisdictional Labor Disputes-The Supreme Court's Gift to Embattled Employers, 15 U.C.L.A. L. REv. No. 3 (April, 1968); Jones, On Nudging and Shoving the National Steel Arbitration Into a Dubious Procedure, 79 HARV. L. Rev. 327 (1965).

53 In fiscal 1965, a total of 15,219 unfair labor practice cases were disposed of; $85.5 \%$ were closed after a charge was filed but before the issuance of a complaint. Another $5.5 \%$ went after issuance but before opening of a hearing. Another $.8 \%$ dropped out after commencement of the hearing and before the trial examiner's decision. After the latter, $1.3 \%$ were closed before issuance of a Board decision, and $.7 \%$ after a Board adopting the trial examiner's decision in the absence of exceptions. That left 951 cases, $6.2 \%$ of the total. Of them, $540,3.5 \%$ of the overall total, were closed after the Board's decision and before circuit court decree. Of those remaining, 359, or $2.4 \%$ of the bulk, were closed after circuit court decree and 52 , or $.3 \%$, only after Supreme Court action. 30 NLRB ANN. ReP. 191, table 8 (1965). 
but in order to force unwarranted settlements or to inflict undue embarrassment, harassment or oppression on the party against whom discovery is sought. Even though there are relatively few who now deplore judicial discovery, the potential for abuse is there. It may subject parties and nonparties to burdens of cost and inconvenience disproportionate to the significance of the litigation to those who must bear the burdens. It may entail delay. It may encroach on personal or professional privileges. Broad probing into the outer reaches of relevancy is now countenanced and the rote invocation of "fishing expedition" has lost its force through sheer repetition.

If that is possible in court litigation, what of labor arbitration? The foreseeable abuses are not very different from those which occur from time to time in adjudication. Would arbitral discovery be used to blackmail settlements? to harass, oppress or unwarrantably to embarrass? or to engage in dilatory tactics? Would its availability result in lazy or incompetent counsel or in overreaching bargainers embarking upon "fishing expeditions" to seek improper entry to the files for economic data of future bargaining value or, as to the immediate grievance, to poach on the other side's preparation of its case? Would abuses be indulged without rebuff by unduly lenient or unsophisticated arbitrators?

Professor Charles Allen Wright has observed that discovery has been "extremely popular with the bar." 54 This is so despite the fact that "there is little opportunity to obtain appellate review of discovery rulings. Such rulings are not final orders and are not appealable as such." 55 Surveys of lawyers practicing under the Federal Rules confirm the popularity of discovery. ${ }^{56}$

The 1948-51 Speck study of the uses of discovery in federal courts disclosed the interesting fact that the remedies are popular and extensively employed ${ }^{57}$ even though the lawyers interviewed were convinced that relief from an abuse of discovery could not be obtained from judges either because judges could not learn enough about the case at the pre-trial stage to rule effectively or because of trouble, expense and delay in obtaining relief. ${ }^{58}$ Abuses were felt to be isolated incidents in a generally valuable procedure. Speck concluded from his interviews that "curtailment of abuse must depend upon the alertness of judges in recognizing harassment and their firmness in enforcing

54 2A W. Barron \& A. Holtzoff, Federal Practice and Procedure $\S 641$ at 11 (Wright ed. 1961).

55 C. Wright, Handbook on the LaW of Federal Courts 312 (1963).

56 Wright, Wegner \& Richardson, supra note 37, at 103-05.

57 Speck, The Use of Discovery in United States District Courts, 60 YALE L.J. 1132, 1155 (1951).

$68 I d$. at 1153 . 
the responsibilities of lawyers as officers of the court." 59 Significantly for arbitral discovery, the lawyers saw deliberate harassment as selflimiting, partly because it is costly to harass, but mostly because of the unfavorable impression that such distasteful conduct has on the decisionmaker. Indeed, the practitioners felt that abuses were limited to multijudge federal districts where a discovery judge would not try the case later. "Lawyers do not care to go to trial before a judge who has ruled on their discovery abuse." ${ }^{60}$ Much less would counsel want to convince his sole arbitrator that his case was credible despite a discovery abuse. Although doubting the utility of discovery in arbitration, Robben Fleming has proposed several guidelines for achieving arbitral discovery while minimizing the potential for abuse. He would recognize an obligation, absent a showing of prejudice, to make relevant information available in an arbitration proceeding at the request of an arbitrator. ${ }^{11}$ Assuming the arbitrator has no subpoena power, he suggests that "an inference be drawn against the party refusing to produce the evidence." ${ }^{2} \mathrm{He}$ also suggests that the arbitrator protect a party, on request, by excising irrelevant portions of a document after privately inspecting it. Contemplating perhaps the key objection to arbitral discovery, he concedes that "there is doubtless a considerable temptation in arbitration proceeding to embark on 'fishing' expeditions," but he concludes that, "even so, the experienced arbitrator will have little difficulty dealing with such cases." 63

Further protection to both the would-be discoverer and his adversary could be provided by application of a Jencks ${ }^{64}$-type rule in arbitration. Such a rule would assure access to relevant data despite a claim, other than one of privilege, that such data is confidential. Jencks has been applied to compel production of NLRB file data in an unfair labor practice proceeding. ${ }^{65}$ As one court observed,

The production and inspection, and possible use for crossexamination purposes, of such a document could serve only to test the memory and credibility of the witness, while, in the

$59 I d$.

60 Id. at 1152 .

61 R. Fleming, supra note 34 , at 68 . Fleming imaginatively suggests the possibility of agreement to use apprentice arbitrators in routine discovery-type matters for nominal fees. Id. at 175. It may well be that the AAA and FMCS could establish a panel of arbitrators who would have indicated their willingness to undertake to handle discovery matters on a fixed fee basis reflecting the lesser demand on their time of routine discovery situations.

62 Id, at 175 .

$63 I d$.

64 See Jencks v. United States, 353 U.S. 657 (1957).

65 See NLRB v. Capitol Fish Co., 294 F.2d 868 (5th Cir. 1961) ; NLRB v. Adhesive Prods. Corp., 258 F.2d 403 (2d Cir. 1958) ; Schauffler v. Teamsters Local 107, 196 F. Supp. 471 (E.D. Pa. 1960). 
absence of a claim of confidence or privilege, there can be no sound reason to bar such production. The request in the case at bar was not a mere fishing expedition, but rather concerned the credibility of the most important witness who testified in support of the charges. ${ }^{66}$

Fleming concludes that "the principle of Jencks is as sound for the arbitrator as for the administrative agency." 67

While the actual potential for abuse inherent in arbitral discovery may not be easy to assess, it is important to realize that the experience with judicial discovery has, on the whole, been quite satisfactory to those who routinely participate in it.

\section{The Impact on Testimonial Privileges}

There are clearly foreseeable circumstances in which an individual's testimonial privileges may be jeopardized by arbitral discovery. The hazard, however, is endemic to arbitration; arbitral discovery would not create it. A witness under subpoena to testify has several privileges entitling him to decline to answer even relevant questions. The principal one, of course, is the constitutional privilege against self-incrimination. Other important privileges may be conferred by statute or common law, depending on the particular jurisdiction in which the testimony is being taken. Perhaps the most notable is the privilege against compelled disclosure of confidential communications between persons in certain protected relationships: husband-wife, lawyer-client, clergymen-penitent, newsman-informant, and public official-informer. ${ }^{\text {ss }}$ Either person in such a relationship is entitled to claim his privilege of silence. ${ }^{69}$

In Malloy $v$. Hogan, ${ }^{70}$ the Supreme Court held that the federal constitutional privilege against self-incrimination is binding on the states through the fourteenth amendment. The Court's reasoning is important for those who think that arbitration can maintain a legally neutral existence, aloof from consideration of public policy. "It would be incongruous," wrote Mr. Justice Brennan for the Court,

to have different standards determine the validity of a claim of privilege based on the same feared prosecution, depending

66 NLRB v. Adhesive Prods. Corp., 258 F.2d 403, 408 (2d Cir. 1958).

67 R. Flemrng, supra note 34 , at 174.

68 It is not, of course, suggested that all of these privileges apply throughout the United States.

69 For a discussion of these privileges in labor arbitration proceedings, see Jones, Evidentiary Concepts in Labor Arbitration: Some Modern Variations on Ancient Legal Thennes, 13 U.C.L.A. L. REV. 1241, 1286-93 (1966).

70378 U.S. 1 (1964). 
on whether the claim was asserted in a state or federal court. Therefore, the same standards must determine whether an accused's silence in either a federal or state proceeding is justified. $^{71}$

Similarly, no distinction should be tolerated between different tribunals. Therefore, it must be assumed that the constitutional guarantee will be applicable to arbitration. The real problem is that of waiver. It would be difficult to conclude that the constitutional privilege is being honestly administered if it can be held that an ignorant witness, without aid of counsel and without warning from the arbitrator, effectively "waived" his privilege to remain silent in later proceedings.

Thus, this problem is not properly regarded as an arbitration issue. No matter what the arbitrator may or may not have done, or what the intent or knowledge of the arbitration witness may have been, a court later confronted with the claim of privilege certainly should not feel bound if the arbitrator erroneously assured the witness that he could testify in the arbitration without losing his right to be silent on the subject in any subsequent proceedings. ${ }^{72}$ Action or inaction in an arbitral tribunal should not be controlling in the determination of important constitutional law issues, quite aside from the fact that at least half of the arbitrators are not legally educated. The conclusion that arbitrators' decisions on claims of constitutional privilege should not have any effect adverse to the claimant in subsequent judicial proceedings eliminates a major constitutional problem which might otherwise plague the development of labor arbitration. ${ }^{73}$

Apart from problems of a constitutional dimension, arbitration is faced also with situations where disclosure may impinge on rights of privacy. Experience indicates, however, that casual breaches of privileged communications would be no more likely at hearings than at cocktail parties. Arbitrators will be reluctant to grant discovery orders

$71 \mathrm{Id}$. at 11 .

72 There is a difference between that situation and the one in which nobody at the arbitration hearing recognizes a privilege problem when it occurs. But the difference does not warrant any distinction. In either event, a later tribunal should not regard the witness to have waived a privilege. One valuable immediate result of that conclusion is to relieve the arbitral tribunal of a responsibility it is not institutionally competent to discharge.

${ }^{73}$ At the same time, it must be admitted that even the partial disclosure of privileged information which results in investigatory leads can distort an innocent reality into the appearance of guilt. It is often the case that a lawyer will counsel his innocent client to invoke his privilege of silence so that a particular fact will not be disclosed, because it would tend to create a false impression of wrongdoing. That kind of "investigatively useful" disclosure may occur in an arbitration, for example in a discharge case involving acts also constituting a crime. There is little anybody can do to remedy the situation, nor should a remedy be attempted; the problem is not so great in incidence as to warrant the severe impact on the arbitral process which would result were courts to undertake to deter this kind of disclosure by invalidating awards of arbitrators when such disclosure has improperly occurred in the course of a hearing. 
prying into private relationships, and will probably require a greater showing of relevance in such cases. The likelihood is that no great problem of transgression on this kind of secrecy privilege would be created in arbitration.

\section{Is Arbitral Discovery One-Sided?}

Closely related to the fear that discovery procedures would be subject to abuse is the fear that the procedures would function as a one-sided remedy favoring unions at the expense of employers. The most obvious response can be found in an analysis of the discovery situations examined in Blind Man's Buff ${ }^{74}$ in which it was to the employer's advantage to gain discovery. But there is more to be said.

Traditionally, hostility to broader discovery has come from management counsel who fear that unions will use discovery to compel advance disclosure of management bargaining data. Employers are naturally somewhat reluctant to share their negotiation data with union bargainers-such disclosure would be greatly feared if unions were permitted to launch inquisitive forays in the nature of discovery quiz sessions, whether ancillary to court or to arbitral proceedings.

Despite this fear, there are significant advantages for both sides in being able to bring to arbitration whatever discovery problems arise in the course of administering the collective agreement. The union's interest is more immediately evident than the employer's-perhaps it is even more significant. Refusal to disclose will be a reaction more common to employers, because, as the employment relationship normally functions, the employer at the outset will generally possess more data relevant to the grievance than are immediately available to the union. This will often be of no particular consequence to the union, because the events and reasons for the challenged action will be discussed by the employer and union representatives during the grievance procedure. But there are cases in which the employer is reluctant to make voluntary disclosure-cases in which the union must have disclosure if it is to exercise its prerogatives both as the employees' representative and as the contracting party. In those circumstances, it is irrelevant to ask whether the employer will benefit from arbitral discovery. It is enough that the need for disclosure exists.

Significantly, some employers have sought to steer discovery efforts by unions into arbitration and away from section 8(a)(5) charges. ${ }^{75}$ This is a sound choice when the employer wishes not only

74116 U. PA. I. REv. 571 (1968).

75 See, e.g., NLRB v. Otis Elevator Co., 208 F.2d 176, 178 (2d C1r. 1953); O'Brien, Should the NLRB Arbitrate Labor Contract Disputes?, 6 WASHBURN L.J. 39 (1966). 
to avoid disclosure, but also to have the matter resolved as soon as possible. Arbitration gives him a decision-maker whom he has had some voice in selecting. But employers cannot exercise a preference for arbitral discovery until that procedure is sanctioned by the NLRB as well as the courts. For the employer, it would be ironic indeed if the alleged one-sidedness of the remedy were a factor in preventing that sanction.

Possibly management's greatest fear of the one-sidedness of arbitral discovery rests on the assumption that it will result in "fishing expeditions." "76 Some protection may be afforded if superintending courts are willing to give real meaning to the concept of relevance. Since federal law ultimately will be applicable to arbitral discovery by way of section 301 of the LMRA, ${ }^{77}$ the "good cause" limitations of Federal Rules 30 (d) and 34 will be available to act as a check on "fishing expeditions." 78

A related problem, that of unwarranted intrusion into counsel's preparation of the case, may be somewhat illusory. The federal courts have evolved elaborate rules to protect an attorney's "work product." These rules will be available where the labor-management relationship affects interstate commerce. ${ }^{79}$ Hickman $v$. Taylor ${ }^{80}$ is the landmark case dealing with discovery of the "work product of the lawyer." If the material is protected by the attorney-client privilege it is not discoverable. If it is not so protected, however, it may still be undiscoverable under Hickman if it comprises "written statements, private memoranda and personal recollections prepared or formed by an adverse

76 One management attorney described his fear as follows:

Due to the fact that there is a continuing relationship, there are all kinds of grievance committees. You have those that are out looking for grievances, who are continuously trying to drum them up. If you give them a right of discovery, which they would like to have, and you let unsophisticated people use this right of discovery, and maybe give an unsophisticated arbitrator the right to award it, you are going to have them asking for information which, by stretching, could be termed "relevant," but really is not. I have been on some Iabor Board cases where they asked for every record you owned, and the Trial Examiner gave it to them because it had some little relevance.

So you have a committee or a local union president who says, "I want this, this, this, and this," and it is relevant, but he wants it for more than one reason. Or if he doesn't at the time want it for more than one reason, he sees a lot of good reasons for having it once he has got it and it could certainly be of use.

I would fight that to the death, I will tell you right now.

Problems of Proof in Labor Arbitration 225 (Proceedings of the 19th Ann. Meeting, Nat'l Academy of Arbitrators, D. Jones ed. 196\%).

77 LMRA 29 U.S.C. \$ 185 (1964).

78 See WRIGHT, supra note 55 , at 312 .

79 State law is of no force except as it may be federalized by selective adoption.

See Teamsters Local 174 v. Lucas Flour Co., 369 U.S. 95 (1962) ; Charles Dowd Box

Co. v. Courtney, 368 U.S. 502 (1962); Textile Workers v. Lincoln Mills, 353 U.S.

448 (1957).

80329 U.S. 495 (1947). 
party's counsel in the course of his legal duties." 81 But that reasoning does not insulate all written materials obtained or prepared by a lawyer in anticipation of litigation. Although one who seeks discovery of a lawyer's "work product" bears the burden of making a substantial showing of "necessity or justification," the Court concluded that "relevant and non-privileged facts" will not be allowed to "remain hidden in an attorney's file." 82 Yet so much of the work product as may reflect his mental impressions or opinions is, "for practical purposes, absolutely immune from discovery." 83

The Court did not extrapolate the work-product rules to cover materials obtained by persons other than attorneys. Although most courts would probably agree that documents are not discoverable when they reflect the impressions or opinions of non-lawyer investigators or insurance claim agents, most cases have held that records of statements obtained by them from witnesses are not entitled to work-product immunity. ${ }^{84}$ Thus, statements elicited during grievance investigations by union business representatives, shop stewards, industrial relations managers or management staff personnel probably would be discoverable, but their personal assessments of probable credibility and weight to be given in a prospective arbitration would not be.

Although the Advisory Committee on the Federal Rules proposed in 1946 that the rules be amended to extend immunity to information obtained by a party to an action or his agent, ${ }^{85}$ there is as yet no such immunity. Therefore, it is common to find that reports made to a corporate party by its agents in the routine course of business are discoverable. ${ }^{88}$ But such an approach is simplistic: the nature of the document and the factual situation in the particular case should be the determinants of work-product immunity. Thus, memoranda accumulated in the course of the administration of a grievance procedure during a contract term, for instance, even though antedating the particular grievance which occasions a discovery effort, should be entitled to immunity because of the special nature of the process of grievance settlement. Unlike one-shot court litigation, grievance administration is a continuous process; a party's method of operation in grievance administration is developed over a long period of time. Should a party be forced to open its tactical files to discovery, its bargaining position in future negotiations might be undermined. The result would

81 Id. at 510.

$82 I d$. at 511 .

83 WRIGHT, supra note 55 , at 314 .

$84 I d$. at 314-16.

$85 I d$. at 316.

86 See Taine, Discovery of Trial Preparations in the Federal Courts, 50 Coluar.

L. REv. 1026, 1039-41 (1950). 
be a serious impairment of the overall efficiency of the dispute resolution process.

\section{B. The Labor and Commercial Arbitral Processes-"Institutional Competence" to Administer Discovery}

The conclusion that discovery and labor arbitration are incompatible often appears to be based on a fallacious analogy to commercial arbitration. This conclusion does not withstand analysis when applied to labor-management grievance procedures.

The Supreme Court in United Steelworkers v. Warrior \& Gulf Navigation $\mathrm{Co}^{87}{ }^{87}$ pointed out the distinction between commercial and labor arbitration processes:

[T] he run of arbitration cases . . . [is] irrelevant to our problem. . . . In the commercial case, arbitration is the substitute for litigation. Here arbitration is the substitute for industrial strife. Since arbitration of labor disputes has quite different functions from arbitration under an ordinary commercial agreement, the hostility evinced by courts toward arbitration of commercial agreements has no place here. For arbitration of labor disputes under collective bargaining agreements is part and parcel of the collective bargaining process itself. $^{88}$

The parties to collective bargaining agreements do not merely choose between trials in courts and proceedings before arbitrators. Rather, the choice is between labor peace achieved through a tribunal responsive to employer-employee grievances and labor unrest caused by resolution of disputes through economic combat. Unlike the parties to commercial arbitration, collective bargainers do not really have a fundamental interest in avoiding procedural limitations. The election of arbitration, as an alternative to strikes and lockouts, in no sense warrants the perfunctory conclusion that a particular arbitral adaption of legal procedures or doctrines, including discovery, is "inconsistent

87363 U.S. 574 (1960).

88 Id. at 578 (emphasis added). The Court compared the commercial and labor arbitration processes in the following words:

Courts and arbitration in the context of most commercial contracts are resorted to because there has been a breakdown in the working relationship of the parties; such resort is the unwanted exception. But the grievance machinery under a collective bargaining agreement is at the very heart of the system of industrial self-government. Arbitration is the means of solving the unforeseeable by molding a system of private law for all the problems which may arise and to provide for their solution in a way which will generally accord with the variant needs and desires of the parties. The processing of disputes through the grievance machinery is actually a vehicle by which meaning and content are given to the collective bargaining agreement. Id. at 581 . 
with the desires of parties who refer their disputes to arbitrators rather than to formal judicial tribunals." 89

Discovery must be carefully administered in accordance with the safeguards implicit in the Federal Rules and emphasized by the Court in Hickman v. Taylor..$^{20}$ For this reason the role of experienced counsel is vital in judicial discovery. Professor Louisell, a close observer of discovery, has cautioned that "[t]he utility, workability and success of discovery will ultimately not be as much a function of threats and sanctions as of its acceptance in reasonable fashion by the trial Bar." ${ }^{21}$ Can arbitral discovery be expected to function within those professional boundaries? Is such professional guidance attainable if discovery procedures are made available to labor arbitration participants? In many of the foreseeable situations in which arbitral discovery would be needed, lawyers would probably be representing the disputants. ${ }^{92}$

But whatever our faith in the capabilities of the representative of the parties-lawyers or laymen-it is evident that in our consideration of the desirability of providing discovery in arbitration we must constantly refer to the prudence of the arbitrator. A very wise and perceptive federal judge, the late Charles E. Clark, observed of the Federal Rules that, "[n]o procedure is better than the men who operate it, while a comparatively poor procedure can be made to work by good men. And so I have never thought much of the power of abstract rules to make judges function better than their innate capacities lead them to do." 93

89 Developments in the Law-Discovery, 74 HARv. L. REv. 940, 943 (1961). However, legal acceptance of arbitral discovery must not result in the removal of discovery disputes from arbitrators to courts. An apt formulation of a rule to govern the interaction of labor arbitrators and courts in discovery situations was given by a New York court in Katz v. Burkin, 3 App. Div.2d 238, 160 N.Y.S.2d 159 (1957) :

Arbitration is subject to its own rules and practices at variance with court procedures. ... It would be generally incompatible with the nature and scope of an arbitration proceeding to allow a shift to the court forum of that part of a proceeding related to the prehearing examination of witnesses or collection of evidence.

Id. at 239,160 N.Y.S.2d at 160 . The court went on to say that judicial intervention should only be granted "under extraordinary circumstances such as the demonstrated need for reaching a witness or evidence which is unavailable without a court order." "Necessity rather than convenience should be the test." Id.

90329 U.S. 495 (1947).

${ }^{91}$ Louisell, Discovery Today, 45 CALIF. L. REv. 486, 511 (1957). Five years earlier he had written, "Implicit in the discovery rules is acknowledgment that they will be administered by a learned profession of judgment and integrity, which can be depended upon for a high degree of self-discipline and self-policing." Louisell, Discovery and Pre-Trial Uiuder the Minnesota Rules, 36 Mins. L. Rev. 633, 646 (1952).

92 Even without their attorneys, the parties are well accustomed to tactics employed to elicit information; they are fairly sophisticated. Most experienced arbitrators, although unfamiliar with judicial discovery, would have no difficulty recognizing and coping with overreaching attempts at bargaining advantage through demands for information.

93 Clark, Pre-trial Orders and Pre-trial as a Part of Trial, 23 F.R.D. 506 (1958). 
Commercial arbitration is a process quite distinct from labor arbitration, economically, psychologically and legally. To a great extent those who function as arbitrators in nonlabor disputes serve infrequently and without compensation. The American Arbitration Association has expressed the consequent reality thus:

As commercial arbitrators serve without fee in the typical AAA case, they cannot usually be called upon more often than, let us say, once or twice a year. It goes without saying that such service does not give the businessman-arbitrator the equivalent of a judge's or even a practicing lawyer's experience in resolving conflicts of evidence, distinguishing truth from error in an adversary proceeding, and maintaining a judicial atmosphere. ${ }^{94}$

Professor Mentschikoff observes of the AAA that it "tries very hard and very successfully not to have any one person sit as an arbitrator more than once or twice a year." 95

The major difference between commercial and labor arbitration, then, is the composition of their respective corps of arbitrators. There are nearly 20,000 persons identified as available for commercial arbitration in the United States, 18,000 of whom are on the AAA panel..$^{96}$ Most of them are never even called to sit on a case. The vast majority of those who have been called will have encountered only a handful of cases in their lifetimes. As knowledgeable as these men and women undoubtedly are in regard to the activities which form the substance

94 Editorial, The "Hazards" of Commercial Arbitration, 17 ARB. J. (n.s.) 65, 66 (1962).

95 Mentschikoff, Commercial Arbitration, 61 CoLUM. L. REv. 846, 857 (1961).

In the Chicago study of decision-making, a survey of trade associations produced 547 responses which disclosed that $34 \%$ of them indicated that their members made individual arrangements for arbitration; $29 \%$ indicated that they used some type of organized machinery, including the American Arbitration Association; and $26 \%$ reported that their members never arbitrate. Of the 128 trade associations reporting existence of institutionalized arbitration machinery, $73 \%$ indicated it was organized and serviced by either the trade association itself, or by one of the four federated associations; $27 \%$ had arrangements with the AAA. The AAA administered commercial cases totaling 677 in 1957; 711 in 1958; 707 in 1959; and 820 in 1960. Id. at 857. Significant differences in practice exist as between the $A A A$ and the self-contained trade association groups' arbitration machinery: (1) under trade association machinery there is "a continuity in the membership of the deciders"" not so under the "casual system" of the AAA, id. at 857 ; (2) precedents are common in the associations, whereas the AAA "puts enormous pressure on its arbitrators not to write opinions," $i d$. at 857 ; (3) the associations either explicitly discourage or forbid the use of attorneys $(40 \%)$ or they "very rarely appear" $(60 \%)$ whereas the AAA actively encourages the use of attorneys, $i d$. at $857 ;$ (4) the sanction for enforcing awards in the associations is internal discipline of the offending member whereas the AAA looks to enforcement of awards by a court of competent jurisdiction, id. at 858; (5) "very few of the [association] arbitrators are lawyers or law-trained" in contrast to about $30 \%$ in AAA cases, $i d$. at 859 ; $(6)$ unlike the trade association machinery, AAA arbitrators "in many cases" have "no peculiar expertise in the particular trade or business involved in the dispute." Id. at 860 .

98 S. Lazarus, J. Bray, I. Carter, K. Collins, B. Giedt, R. Holton, P. Matthews, G. Willard, Resolving Business Disputes 23 (1965). 
of their careers, they typically have no practical experience whatsoever in the problems of conducting hearings or in the intricacies of the "judgematical" problem, the skeptical sifting of fact and argument in the formulation of a judgment which will bind the disputants in an adversary proceeding. Little wonder that judges and lawyers would look aghast at the prospect of a single-case businessman-arbitrator administering discovery procedures!

In contrast, labor arbitration is unique. Today there is a corps of several hundred experienced labor arbitrators throughout the United States hearing and deciding thousands of cases each year. ${ }^{97}$ These persons have acquired experience because union and management specialists in labor relations have repeatedly joined to ask them to serve as their arbitrators. Their acceptability is based upon continuing observation of their capacity to perform the functions desired by the disputants. The National Academy of Arbitrators was organized in 1947 "to establish and foster high standards and competence among those engaged in the arbitration of industrial disputes on a professional basis." Its membership is composed of persons with "substantial and current experience as . . . impartial arbitrator [s] of labor-management disputes" or persons with "limited but current experience" who have "attained general recognition through scholarly publication or other activities as . . . impartial [authorities] on labor-management relations." Also taken into account is a prospective member's "general acceptability to the parties." 98 The Academy numbers only about 350 members even though it has no in-group exclusionary policies. A 1962 Academy survey of arbitrators, covering 58 per cent of its membership, revealed that the 158 respondents had decided 6279 cases in 1962, an average of 39.8 per arbitrator. ${ }^{99}$ A 1964 survey pegged the average at 40.1. ${ }^{100} \mathrm{My}$ own current survey of American labor arbitrators indicates that there may be considerably fewer active arbitrators than has generally been assumed, probably less than 450 .

97 The AAA maintains a 1500-man labor arbitration panel nationally, but about 400-500 actually sit as arbitrators. The balance appear to have the requisite qualifications but apparently have not proved acceptable. FMCS General Counsel Morris Myers has stated that $25 \%$ of the 1000 arbitrators on the FMCS roster get $75 \%$ of the cases. There are men on the panel, again with the requisite qualifications, whose names may be submitted 70 or 80 times a year without being accepted once by the parties to a grievance dispute. This is all the more disappointing when one realizes that these panels each require an existing measure of acceptance by labor and management representatives plus, in the case of the FMCS, arbitral experience or prior indepth involvement in the process. Furthermore, there is "a substantial overlap between the FMCS and AAA panels." 64 LAB. REL. REP. 341 (1967).

38 See 1966-67 Membership Directory, National Academy of Arbitrators 2-4 (Statement of Academy Purposes and Aims, and Statement of Policy Relative to Membership).

${ }_{92}$ Labor Arbitration-Perspectives and Problems, 17 NAT'L ACAD. OF ARB. PRoCEEDINGS 292, 295 (M. Kahn ed. 1964).

10018 NAT'L ACAD. of ARB. Proceedings 243, 244 (D. Jones ed. 1965). 
Thus a relatively small corps of experienced and acceptable, impartial persons handles the bulk of grievance cases. This is an important consideration in determining the availability of a federal arbitral discovery remedy. It also confirms the Supreme Court's reasoning in United Steelworkers v. Enterprise Wheel \& Car Corp. ${ }^{101}$ that

When an arbitrator is commissioned to interpret and apply the collective bargaining agreement, he is to bring his informed judgment to bear in order to reach a fair solution of a problem. This is especially true when it comes to formulating remedies. There the need is for flexibility in meeting a wide variety of situations. ${ }^{102}$

The wide experience of these labor arbitrators gives them expertise, comprised of insight gathered from years of walking into plants they have never before entered and reacting to people they have never previously met, in order to hear, with varying degrees of formality and vehemence, about kinds of disputes they will already have observed in a variety of industrial contexts. Their experience is markedly unlike that of the judge who sits in the routinized and formal atmosphere of a courtroom into which the disputants come in awe and some trepidation. It is also unlike that of the members of the National Labor Relations Board for much the same reasons as apply to the courts. The Labor Board sits in Washington. Its cases travel to Washington, past the monuments and columns of the nation's capital, and arrive in the vast masonry of federal government. In contrast, the arbitrator drives out to the plant, or to some employer association or union hall conference room. He rides circuit as did judges in the old American tradition, bringing the apparatus of justice to the immediate locale in which it has been invoked. On balance, this experience and exposure to problems of industrial relations tends to confirm the conclusion that arbitration provides the most direct access to collective bargaining discovery administered by decision-makers likely to be informed and sophisticated in dealing with the types of problems comprising the discovery dispute.

Furthermore, Professor Mentschikoff has observed that:

[the] right to participate in and, in large measure, to control the selection of arbitrators affords persons using the arbitral procedure an enormous advantage over those using the courts, since in the courts, within narrow limits of tactical maneuvering, the parties have no say in the selection of the judge who will try the case. ${ }^{103}$ 
Chief Justice Roger Traynor of the California Supreme Court recently observed that "in the judiciary, as in every other walk of life, a bad man is as hard to lose as a good man is hard to find." ${ }^{104}$ The legal practitioners in labor-management relations, the employer associations and the international unions, keep themselves informed about reputations, and an arbitrator stands for election each time he is considered by the parties for appointment. Incompetents become identified in this professional environment and are ostracized.

Despite the industrial relations experience of most labor arbitrators, there are some who question whether theirs should be insulated or enforceable decisions. Is it prudent to entrust discovery to arbitrators? Are they competent to discharge the responsibility involved? In a curiously intemperate Storrs lecture at Yale, ${ }^{105}$ Judge Paul R. Hays, erstwhile arbitrator and labor law professor, brusquely condemned (with almost no factual documentation and with an appalling lack of concern for the individuals thus defamed en masse) all but an unnamed "handful" 106 of arbitrators as "venal incompetents." Judge Hays declared the "many fatal shortcomings" of labor arbitration to be beyond repair by courts. Therefore, he concluded that "the courts should not lend themselves at all to the arbitration process." ${ }^{107}$ The essence and tenor of his view may be gathered from the following:

In literally thousands of cases every year decisions are made by arbitrators who are wholly unfitted for their jobs-who do not have the requisite knowledge, training, skill, intelligence and character.

A proportion of arbitration awards, no one knows how large a proportion, is decided not on the basis of the evidence or of the contract or other proper considerations, but in a way which in the arbitrator's opinion makes it likely that he will be hired for other arbitration cases. . . .

We know that a large proportion of the awards of arbitrators are rendered by incompetents, that another proportion-we do not know how large but are permitted by the circumstances to suspect that it is quite large-is rendered on the basis of what award would be best for the arbitrator's future. . . . (1967).

104 Traynor, Who Can Best Judge the Judges? 42 CAIIF. STATE B.J. 225, 238

105 P. Hays, Labor Arbitration: A Dissenting View 112 (1966) :

There are only a handful of arbitrators who, like Shulman and Cox, have the knowledge, training, skill, and character which would make them good judges and therefore make them good arbitrators.

$106 \mathrm{Id}$.

$107 I d$. at 113. 


\title{
... [L]abor arbitration is a usually undesirable and frequently intolerable procedure. . . . ${ }^{108}$
}

\author{
Judge Hays made very little pretense of documenting his "we know"
} assertions, or the "circumstances" which led him to such a dismal view. ${ }^{109}$ That both the labor arbitration process and the judicial process need improvement is patent. They are human institutions. That

$108 I d$. at $113-14$.

The charge that arbitrators generally are not qualified for that kind of task has been fired from time to time over the centuries. Mr. Justice Story's observations in 1845 have already been noted. See notes 2-6 sitpra and accompanying text. In marshalling his reasons for disapproving of arbitration, Mr. Justice Story cited a string of English decisions to demonstrate that an agreement to refer a claim to arbitration could not be specifically enforced. Yet only a decade later, Lord Campbell was successfully urging the House of Lords in Scott v. Avery, 25 L.J. Exch. 308 (1856), to take a contrary view of public policy. Plaintiff there argued in a contract action that an insurance company could not assert as a defense that the matter had not yet been submitted to arbitrators for determination of the amount of loss, as provided in the contract of assurance. The contractual provision was argued to be an improper effort to oust the courts of jurisdiction, and therefore void as against public policy.

Lord Campbell commented on the origin of the doctrine that parties could not by contract oust the courts of their jurisdiction in favor of arbitration. The report of his remarks on this aspect of the case is interesting:

There could be no injury to the public in an insurance company contracting that no action should be brought against it, the costs of which might be ruinous, but that every dispute should be referred to a domestic tribunal which might speedily and economically determine the dispute. Public policy seemed to him to require that such a contract should be enforced. If there were any decisions the other way, he should ask their Lordships to reverse them as contrary to principle. The doctrine had its origin in the interests of the Judges. There was no disguising of the fact that, as formerly, the emoluments of the Judges depended mainly, or almost entirely, upon fees, and as they had no fixed salary there was a great competition to get as much as possible of litigation into Westminster Hall, and a great scramble in Westminster Hall for the division of the spoil. . . . And they had great jealousy of arbitrations whereby Westminster Hall was robbed of those cases which came not into the King's Bench, nor the Common Pleas, nor the Exchequer. Therefore they said that the Courts ought not to be ousted of their jurisdiction, and that it $I d$. at 313 . was contrary to the policy of the law to do so.

In an ironic turnabout of concern for the implications of the fee system, Judge Hays has made the following observations:

A system of adjudication in which the judge depends for his livelihood, or for a substantial part of his livelihood or even for substantial supplements to his regular income, on whether he pleases those who hire him to judge is per se a thoroughly undesirable system. In no proper system should a judge be submitted to such pressures. On the contrary, a judge should be carefully screened from any pressure of this type. There are many discussions of arbitration which do not mention this aspect of the process. In my opinion no discussion of arbitration that does not consider the effect of the arbitrator's dependence on the good will of the parties is completely honest.

Hays, supra note 105 , at 112-13.

109 The original publication, 74 YALE L.J. 1019 (1965), consisted only of the last of the three lectures and contained no documentation whatsoever. Although Judge Hays did attempt to muster support for his assertions when the lectures were published in book form, supra note 105, he himself admitted that there was a "surprising lack of objective factual studies of the arbitration process." Id. at 38 . As a result, he could support one of his major assertions-that a prediction of how an arbitrator will decide the issue is the sole basis for his selection-only by quoting the answer given by "only one client" to a question propounded in a survey done twenty years ago. Id. at 39 .

That Judge Hays had unpleasant experiences as an arbitrator is unquestionable. His arguments, however, are clearly based almost entirely on these few experiences. 
attempts at reform are necessary is obvious. But to condemn an institution widely and voluntarily accepted is neither sound scholarship nor fair judging.

If labor arbitrators were typically the venal men of Judge Hays' recollection they certainly should not be entrusted with any functions of a judicial nature, let alone discovery. For that matter, they should be ousted from collective bargaining entirely to protect its integrity. But with a kind of pox-on-you attitude toward bargainers foolish enough to arbitrate, Judge Hays oddly appeared willing to tolerate arbitrators so long as their awards just stayed out of court. The labor-management community and their lawyers, however, are toughminded men, competent and interested enough to spot an avaricious or stupid arbitrator and to eliminate him from the process. Judge Hays thinks uniformly well neither of those who do the selecting nor of those who are selected. The judgment of the selectors obviously must be reflected in the men and women they select as their arbitrators. There are inept arbitrators. There are also inept judges. At least in voluntary arbitration the disputants are empowered to jointly accept or reject their own decision-maker. Typcially, they also divide his fee evenly between them (or sometimes assess it against the loser) so neither has a peculiar call on his judgment in the particular case. One who seeks to please the party with the greater number of future arbitrations at his dispensation is truly to be pitied because his chances of success at venality are minimal. Unlike the incompetent judge, the venal or incompetent arbitrator is readily removable from circulation. A judge may be "unacceptable" to a litigant for any one of a number of reasons. But, except in rare circumstances, judge he remains of that case.

Whatever it was that Judge Hays experienced, observed, or heard about, it clearly scandalized him. Were a pattern thereby indicated, we would surely want to determine whether we were confronted with the inherent weaknesses of an institution (and should therefore withdraw our support from it) or with isolated personal venality, not invalidating the institution so much as the man. Unfortunately, he discloses neither source nor circumstance. We may assume that something or some things happened and that the situation was deplorable, since it manifestly shocked an honorable man. The point is, however, that we are assessing an institution of demonstrated utility; there is simply no evidence in the public record of anything other than an occasional unsubstantiated rumor indicating the possibility of isolated instances

While properly pointing out the need for more factual studies of the process, his lectures serve primarily as an illustration of a point he himself makes-that one who writes about arbitration only from his own experiences of the process should be wary of broad generalization from his own limited viewpoint. See id. at 38. 
of venality; there is only the unsubstantiated, blanket condemnation of Judge Hays.

In contrast, Professors Dallas Jones and Russell Smith have conducted an enlightening study of the attitudes of disputants and advocates toward the labor arbitration process. ${ }^{110}$ Given the choice of leaving all issues of contract application to the courts, to bargaining inclusive of strike action or to arbitration, an "overwhelming majority" of those surveyed preferred arbitration. ${ }^{111}$ Not a single union official questioned preferred either courts or bargaining to arbitration. ${ }^{112}$ And although several union lawyers did prefer strikes to arbitration, none wanted to litigate. ${ }^{113}$ Indeed, only five per cent of the management respondents, including lawyers, indicated a preference for a method other than arbitration. ${ }^{114}$

These are crucial findings. There are pointed criticisms of labor arbitration, notably of felt procedural deficiencies concerning conduct of the hearing, rules of evidence, legalisms, reviewability, the need for new faces, delays, cost and, most prominently, the quality of the experience of arbitrators. Yet the general acceptance of arbitration among those who voluntarily resort to it means that the Justices of the Supreme Court who are continuously strengthening the jurisdiction and the authority of labor arbitrators accurately perceive the realities felt by those who participate in the process.

What has been sought in arbitration is the element of informed judgment which it can provide. That judgment is developed by exposure to the problems of a number of different situations and employer-union relationships. The experienced arbitrator develops a capacity to grasp the varying needs, problems, desires and aversions of employers, unions and workers.

In considering the use of discovery procedures administered by arbitrators, it should be remembered that many labor arbitrators are not lawyers. However, this need not present an insurmountable problem: the functional character of the non-lawyer arbitrator's experience and judgment equip him to exercise a sound discretion in the cases he handles. The intrusive character of a remedy resulting in

110 Jones \& Smith, Management and Labor Appraisals and Criticisms of the Arbitration Process: A Report with Comments, 62 MICH. L. REv. 1115 (1964).

111 Id. at 1116.

112 Id. at 1117.

113 Id.

114 Id. at 1116-17.

A substantial number of our respondents not only prefer arbitration over the other available alternatives, but also indicate they are generally satisfied with the arbitration process as they now find it, and offer no suggestions for its improvement. On the other hand, many, although generally of the opinion that arbitration is the best of the viable alternatives, indicate dissatisfactions of various kinds, and hold that the process can and should be improved.

Id. at 1118. 
unwilling disclosure would obviously be a highly sensitive issue to either an employer or a union. A law degree would not seem to be a prerequisite to an understanding of the sensitivity and importance of the problem. If errors in judgment will be made in arbitral discovery, it seems as likely that they will be made by lawyer as by layman arbitrators, and as many non-lawyers are likely to err on the side of denying recovery as on the side of granting it without cause. There is little doubt that discovery would be sparingly granted by arbitrators, whether lawyers or not.

We have been considering the concerns and possible objections which might attend the acceptance of arbitral discovery. We have found that it is a remedy which is compatible with collective bargaining and that it can be structured to provide its administration with adequate safeguards. We turn now to an analysis of the implications to arbitral discovery of the various legal doctrines radiating from the Federal Rules of Civil Procedure, the Taft-Hartley Act, the United States Arbitration Act and other sources of applicable national policy.

\section{III}

\section{The Legal Foundations of Arbitral Discovery}

Professor Louisell has observed that the prospect of discovery in arbitration proceedings "raises fundamental questions as to the nature of arbitration in relation to the total adjudicatory process." 115 So it does, but it is important to bear in mind that arbitration comprehends several processes, only one of which is responsive to collective bargaining disputes. As we have seen, the legal and economic incidents attributable to labor arbitration can only be derived in relation to the economic and political policies which sustain the processes of collective bargaining-the basic national mechanism for allocating and administering the economic benefits of the production of goods and services in major segments of our economy. The need is constant for pragmatic appraisals of the contemporary problems of collective bargaining so that arbitral techniques may be made responsive to them.

\section{A. The Development of Modern Discovery}

Modern discovery has been almost as dramatic in the pace of its development as has labor arbitration. It was only in 1924 that $\mathrm{Mr}$. Justice Folmes, speaking for a unanimous Court, denounced as "contrary to the first principles of justice" the allowance of "a search through all the respondents' records, relevant or irrelevant, in the hope that something will turn up." ${ }^{118}$ Invoking the fourth amendment's 
prohibition of unreasonable searches and seizures, he declared that it would "sweep all our tradition into the fire" were "fishing expeditions into private papers" to be tolerated. ${ }^{117}$

\section{The Hickman Rationale}

Yet less than a quarter of a century later it was as emphatically declared by a unanimous Court in Hickman v. Taylor" that "No longer can the time-honored cry of 'fishing expedition' serve to preclude a party from inquiring into the facts underlying his opponent's case." 119 The writer, Mr. Justice Murphy, was one of the Court's most devoted civil libertarians, sensitive indeed to the safeguards of the Bill of Rights. The Court hailed "the vital role in the preparation for trial" of the recently adopted "deposition-discovery process" of the Federal Rules of Civil Procedure. ${ }^{120} \mathrm{Mr}$. Justice Murphy declared that the "broad and liberal treatment" 121 to be accorded the new rules meant that "civil trials in the federal courts no longer need be carried on in the dark." 122 The "various instruments of discovery" would enable the narrowing and clarifying of the issues between the parties. "To that end, either party may compel the other to disgorge whatever facts he has in his possession." ${ }^{123}$ Disclosure occurs in the course of a trial in any event. The deposition-discovery procedure "simply advances the stage at which the disclosure can be compelled from the time of trial to the period preceding it, thus reducing the possibility of surprise." Of course, discovery "is not a one-way proposition," available to or favoring only one class of litigants. "It is available at the behest of any party, individual or corporate, plaintiff or defendant." 124

As with all matters of procedure, however, discovery "has ultimate and necessary boundaries." ${ }^{25}$ These are the safeguards contained in rules $30(\mathrm{~b})$ and (d) and 31 (d) which are designed to preclude bad faith, annoyance, embarrassment, or oppression of the person subjected to discovery. Rule 26 (b) curbs inquiry into the irrelevant or the realm of privileged silence.

The resistance to more effective discovery has been quite stubborn throughout. Wigmore concluded that the English common law judges

117 Id.

118329 U.S. 495 (1947).

$119 \mathrm{Id}$. at 507 .

$120 \mathrm{Id}$. at 501 .

$121 \mathrm{Id}$. at 507 .

$122 \mathrm{Id}$. at 501 .

$123 \mathrm{Id}$. at 507 .

124 Id.

125 Id. 
resisted it because disclosure to an adversary was "repugnant to all sportsmanlike instincts," ${ }^{126}$ related to the British addiction to the card game of whist which protected the player from exposing his cards before playing them. Another commentator saw the element of surprise so long cherished by the common law as "the psychological child of trial by battle." 127

Whatever the reason, it has certainly been true that there has been a deep fear of liberalizing discovery. Hostility to "fishing expeditions" before trial was finally only overcome by favorable experiences with discovery. The attraction of the sporting theory of justice has consequently, in recent years, been considerably dissipated. Mr. Justice Frankfurter once stated that "[1]itigation is the pursuit of practical ends, not a game of chess." 128 After a quarter century of federal discovery, studies indicate that it is "extremely popular with the bar." 128

Modern discovery procedures are recognized to have contributed to the efficient functioning of the judicial system in several ways. Discovery has helped to narrow the area of controversy, thereby causing settlements and reducing the prospect of unfair surprises.

\section{Arbitral Discovery Among the States}

The liberality of federal discovery rules has had a significant impact on state deposition rules and statutes. But in the twenty-nine years since their adoption, less than half the states have modeled their deposition-discovery procedures on the Federal Rules. Although Judge Charles E. Clark in 1958 saw a "trend of state adoption . . . proceeding apace," ${ }^{130}$ consideration of the arbitral utility of discovery must reckon with the existence in a substantial number of states of disparate discovery practices in the federal and state courts, quite aside from special provisions made for arbitration.

Arbitration statutes have been enacted by most states. ${ }^{131}$ Many of the states have conferred on the arbitrator the power to issue subpoenas ${ }^{132}$ and to administer oaths. ${ }^{133}$ Depositions for discovery pur-

1206 J. WignoRe, EvIDENCE $\$ 1845$ at 375 (3d ed. 1940).

127 G. RAGLANd, Discovery Before Trial 264 (1932).

128 Indianapolis v. Chase Nat'l Bank 314 U.S. 63, 69 (1941).

129 Wright, Wegner \& Richardson, The Practicing Attorney's View of the Utility of Discovery, 12 F.R.D. 97 (1952). See notes 55-59 supra and accompanying text.

130 Clark, Two Decades of the Federal Civil Rules, 58 Colum. L. Rev. 435 (1958). 131 E.g., Mass. Ann. Laws ch. 150C, $\$ 3$ (1965); N. H. Rev. Stat. Ann. $\S 542: 6$ (1955); W. VA. CODE ANN. §21-1Ä12 (1966).

132 E.g., Ala. Code tit. 7, §837 (1958); Conn. Gen. Stat. Ann. \$ $52-412$ (1958); Wis. Stat. ANN. § 325.01 (1958).

133 E.g., Ariz. Rev. Stat. Ann. \$ 12-1507 (Supp. 1966) ; Irl. Ann. Stat. ch. 10, $\S 107$ (Smith-Hurd 1966); N. Y. Crv. Prac. LAw $\$ 7505$ (ḾcKinney 1963). 
poses are enabled in some states; ${ }^{134}$ but others enable the taking of depositions only "for use as evidence." 135

In contrast to Federal Rule 26, the present California arbitration statute limits the use of depositions for discovery purposes in arbitration. An arbitrator "may order the deposition of a witness to be taken for use as evidence and not for discovery." 13e This is so even though California in 1957 became one of those jurisdictions embracing the more liberal federal procedures. ${ }^{137}$ Although the California legislature substantially adopted the language of the Federal Rules, it did not copy them verbatim. Instead, it made quite a few alterations, broadening the scope of discovery. "The importance of those alterations," the Supreme Court of California observed in 1961 in Greyhound Corp. v. Superior Court, ${ }^{138}$ "is that almost without exception they were made for the express purpose of creating in California a system of discovery procedures less restrictive than those then employed in the federal courts." 139

The California court quoted ${ }^{140}$ Professor Louisell's comment that "a law suit should be an intensive search for the truth, not a game to be determined in outcome by consideration of tactics and surprise. . . . [T] he deposition-discovery rules . . minimize the chances for and significance of the trick tactic . . . [and] enhance the value of thorough and penetrating advocacy." 141 Applying that standard to the restrictive arbitral discovery statute, Louisell concludes that it is "an additional hiatus in modern California discovery." 142

At this point, the reasoning of the California court in this nonlabor case affords a useful summary of the goals of discovery, whether in arbitration or the courts. The court saw the liberalized system as intended to accomplish the following results:

(1) to give greater assistance to the parties in ascertaining the truth and in checking and preventing perjury; (2) to provide an effective means of detecting and exposing false, fraudulent and sham claims and defenses; (3) to make available, in a simple, convenient and inexpensive way, facts which otherwise could not be proved except with great difficulty;

134 E.g., Nev. Rev. Stat. \& 38.120 (1957).

135 E.g., Calif. Crv. Pro. Code $\$ 1283$ (West Supp. 1966); Fla. Stat. Ann. $\$ 57.17$ (Supp. 1966); OHIo Rev. Code ANN. \$2711.07 (Page 1954).

136 Cal. Civ. Pro. Code $\$ 1283$ (West 1954).

137 Id. $\$ 2016$.

13856 Ca1.2d 355, 364 P.2d 266, 15 Cal. Rptr. 90 (1961).

139 Id. at 375,364 P.2d at 274,15 Cal. Rptr. at 98.

140 Id. at 375,364 P.2d at 275, 15 Cal. Rptr. at 99.

141 Louisell, Discovery and Pre-Trial Under the Minnesota Rules, 36 Mrnn. L. REv. 633, 639 (1952).

142 D. Louisell, Modern California Discovery 17-18 (1963). 
(4) to educate the parties in advance of trial as to the real value of their claims and defenses, thereby encouraging settlements; (5) to expedite litigation; (6) to safeguard against surprise; (7) to prevent delay; (8) to simplify and narrow the issues; and (9) to expedite and facilitate both preparation and trial. ${ }^{143}$

We turn now to a consideration of the national labor laws to determine how arbitral discovery may square with them and whether federal law, operating through the constitutional doctrine of federalstate preemption, may be said to have replaced the welter of state arbitral discovery systems with the uniformity of a federal arbitral discovery remedy.

\section{B. The Taft-Hartley Act and Arbitral Discovery}

No federal procedures for discovery in labor arbitration are expressly provided for in the Taft-Hartley Act. ${ }^{144}$ Several sections, however, are relevant. Section 203(d) makes the basic policy declaration that

[f]inal adjustment by a method agreed upon by the parties is hereby declared to be the desirable method for settlement

143 Greyhound Corp. v. Superior Ct., 56 Cal.2d 355, 377, 364 P.2d 266, 275, 15 Cal. Rptr. 90, 99 (1961).

144 There have been unsuccessful efforts to obtain inter-party discovery in other federal administrative proceedings. Under the Administrative Procedure Act, 5 U.S.C. $\S 555$ (Supp. II 1966), and the statutes creating the various federal agencies, those such as the NLRB have the power to issue subpoenas and to take depositions and can compel disclosures in proceedings initiated by them. Of the "big seven" regulatory agencies, five have rules sufficiently ambiguous to permit depositions to be taken for discovery purposes. (F.P.C.) 18 C.F.R. $\$ \$ 1-24$ (a), (b) (1961) ; (F.T.C.) 16 C.F.R. \$ 3.10 (a) (Supp. 1964); (I.C.C.) 49 C.F.R. \$ 11.57(a) (1963) ; (N.L.R.B.) 29 C.F.R. $\$ 102.30$ (a) (1963) ; (S.E.C.) 17 C.F.R. $\$ 201.15$ (a) (Supp. 1963). All but the F.T.C. require a showing of good cause. But the APA, as typically construed in the rules of the federal agencies, "fails to provide an administrative litigant with much assistance in his quest for discovery." Note, 16 Stan. L. REv. 1035, 1043-44 (1964). As Professor Kenneth Culp Davis has observed, "[p]robably no sound reason can be given for failure to extend to administrative adjudications the discovery procedures worked out for judicial proceedings." K. DAvis, AdMIMISTRATIVE LAW 589 (1958). See also, Berger, Discovery in Administrative Proceedings, 46 A.B.A.J. 74 (1960) ; Frankhauser \& Belman, The Right to Information in the Administrative Process: $A$ Look at the Securities and Exchange Commission, 18 Av. L. REv. 101 (1966).

The California Supreme Court, in the face of a similar problem, adopted a more candid approach and reached a sounder result in its unanimous decision in Shively v. Stewart, 65 Cal.2d 475, 421 P.2d 65, 55 Cal. Rptr. 217 (1966). Confronted with legislative silence with respect to the availability of pre-hearing discovery in an administrative proceeding, Chief Justice Traynor stated flatly, "We are committed to the wisdom of discovery ...." id. at 479, 421 P.2d at 68, 55 Cal. Rptr. at 220, and concluded that the silence of the legislature did not mean a rejection by it of pre-hearing discovery in administrative proceedings. "Instead, ... it has left to the courts the question whether modern concepts of administrative adjudication call for common law rules to permit and regulate the use of the agencies' subpoena power to secure pre-hearing discovery." Id. at 479, 421 P.2d at 67, 55 Cal. Rptr. at 219 . As the chief justice observed, "statutory administrative procedures have been augmented with common law rules whenever it appeared necessary to promote fair hearings and effective judicial review." Id. 
of grievance disputes arising over the application or interpretation of an existing collective bargaining agreement. ${ }^{145}$

Sections 8(a)(5) ${ }^{146}$ and $8(\mathrm{~b})(3)^{147}$ establish the requirement of good faith bargaining on the part of employers and unions respectively, and section $8(d)$ requires that they

meet at reasonable times and confer in good faith with respect to wages, hours, and other terms and conditions of employment, or the negotiation of an agreement, or any question arising thereunder, . . . but such obligation does not compel either party to agree to a proposal or require the making of a concession. ${ }^{148}$

Finally, under section 9(a), a union selected by a majority of the employees becomes the representative of all workers in the bargaining unit. $^{149}$

\section{From Lincoln Mills to Acme Industrial}

In 1957 the Supreme Court concluded in Textile Workers Union v. Lincoln Mills ${ }^{150}$ that section 301 of the Taft-Hartley Act ${ }^{151}$ empowered the federal courts to fashion a body of law for the enforcement of collective agreements. "The rule that will best effectuate the federal policy" was to be drawn "from the policy of our national labor laws," and, if drawn from state law, the rule "will be absorbed as federal law and will not be an independent source of private rights." 152 In later cases, the Court has noted that the arbitrator is vested with responsibility for rulemaking responsive to the special needs of collective bargaining, because he "performs functions which are not normal to the courts; the considerations which help him fashion judgments may indeed be foreign to the competence of courts." ${ }^{153}$ "The ablest judge cannot be expected to bring the same experience and competence to bear upon the determination of a grievance, because he cannot be similarly informed." 154 The arbitrator's contractual rulemaking power

145 LMRA 29 U.S.C. $\$ 173$ (d) (1964). That policy was articulated earlier in $\$ 8$ of the Norris-LaGuardia Act of 1932 which denies injunctive relief to any complainant "who has failed to make every reasonable effort to settle such dispute either by negotiation ... or voluntary arbitration." 29 U.S.C. $\$ 108$ (1964).

146 NLRA 29 U.S.C. \$158(a) (5) (1964).

147 LMRA 29 U.S.C. \$ 158(b) (3) (1964).

148 LMRA 29 U.S.C. \$158(d) (1964).

149 The Supreme Court and the Board have interpreted these statutory provisions as creating an obligation of disclosure on the part of the employer in the course of the administration of the grievance procedure contained in a collective agreement. See Blind Man's Buff, supra note *, at 578-86.

150353 U.S. 448 (1957).

151 LMRA 29 U.S.C. \$185 (1964).

152 Id. at 457.

153 United Steelworkers v. Warrior \& Gulf Nav. Co., 363 U.S. 574, 581 (1960).

154 Id. at 582 . 
understandably extends to the " 'procedural questions' which grow out of the dispute and bear on its final disposition." 155

The question arises, however, whether section 301 as read by the Court in Lincoln Mills equips labor arbitrators with the same remedial aids, and subjects them to the same procedural safeguards, irrespective of the particular remedial scheme of the state in which the arbitration occurs. Arbitrators must frequently cross state lines in order to function. Substantial advantages would accrue if arbitrators and courts concerned with exercising the "judicial inventiveness" mandated by Lincoln Mills need only focus on one set of federal legal principles. ${ }^{156}$ They would be thereby free to develop expertise and to work out flexible ground rules for each particular arbitration problem. The uncertainties created by non-uniformity ought not to afflict labor arbitration if avoidance is at all possible.

It is reasonable to conclude, in view of the evolution of the interpretation of section 301, that arbitrators possess the power to issue binding discovery orders under federal law preemptive of state law. This includes the power of subpoena, deposition-discovery, and administration of the testimonial oath. The power exists when a party to a collective agreement, anticipating the need for enforcement of discovery procedures, seeks an order in a state or federal court to compel arbitration under section 301 of the Taft-Hartley Act. The discovery remedies of the Federal Rules of Civil Procedure should be deemed to become operative upon filing to secure that enforcement order, regardless of whether a later court order specifically authorizes the use of discovery procedures in the arbitration and irrespective of whether the court is state or federal.

In all but a handful of grievance disputes, the parties may avoid the necessity of judicial intervention under section 301 by agreeing to submit procedural differences to an arbitrator for resolution. Their arbitration proceeds under the aegis of section 301 whether or not formally invoked by a party to the collective agreement through the institution of a court suit. Questions of power and propriety are resolved in either event under federal law. Federal law determines the extent of the arbitrator's powers, including those of subpoena, deposition, and administration of an oath.

155 John Wiley \& Sons v. Livingston, 376 U.S. 543, 557 (1964).

156 In Vaca v. Sipes, 386 U.S. 171 (1967), the Court reviewed its preemption doctrines. It distinguished two lines of evolution stemming from the Taft-Hartley Act, "the Garmon line of decision," referring to San Diego Bldg. Trades Council v. Garmon, 359 U.S. 236 (1959), and section 301 suits. As to the latter, "Garmon and like cases have no application. .." 384 U.S. at 184. Whereas the Garmon doctrine allocates jurisdiction either to the state or federal forum, the section 301 cases have allowed the states a concurrent jurisdiction to apply the federal law evolved under section 301 pursuant to the Lincoln Mills mandate. 
Section 301, not the Federal Rules of Civil Procedure, is the funnel for this federal power. The instrument of federalization in labor dispute arbitration is the congressional mandate of section 301 as construed by the Court in Lincoln Mills. This description of procedural preemption relative to the immediate administration of labor arbitration can be regarded either as a proposal for judicial inventiveness or as an attempt to define an existing state of law. It would be more realistic to view it, however, as a blend of definition and anticipation inherent in an effort to prepare the ground for an act of judicial lawmaking.

The Supreme Court, in its Lincoln Mills-Wiley line of decisions, has developed a rationale of rulemaking for the interaction of arbitrators and courts. In Carey v. Westinghouse Electric Corp. ${ }^{157}$ and in the recent decision in NLRB v. Acme Industrial Co., ${ }^{158}$ it has strongly supported cooperative interaction between labor arbitrators and the Board. Lincoln Mills called upon the courts to exercise a "range of judicial inventiveness that will be determined by the nature of the problem." ${ }^{169}$ That mandate must be read in light of the Court's subsequent emphasis, in the Steelworkers trilogy, upon the particular cast of judgment of arbitrators and upon the inevitability of a functional relationship between them and the courts. ${ }^{160}$

The evolution of the remedy of arbitral discovery, in its turn, fits into the federal scheme of tribunal interaction initiated by Lincoln Mills. Acme Industrial ${ }^{161}$ has committed to the NLRB the task of dovetailing its procedures with those of arbitration, but the Board by no means has an unfettered discretion. In NLRB v. $C \& C$ Plywood Corp., ${ }^{162}$ a case involving a collective bargaining agreement without an arbitration clause, ${ }^{163}$ the Supreme Court noted the significance of the congressional determination to withhold a "general jurisdiction over all alleged violations of collective bargaining agreements" from the Board and to confer it on the courts under section 301. To have conferred on the Board the "generalized power to determine the rights of parties under all collective agreements would have been a step toward govern-

157375 U.S. 261 (1964).

158385 U.S. 432 (1967). See Blind Man's Buff, supra note *, at 578.

159353 U.S. at 457.

160 See United Steelworkers v. American Mfg. Co., 363 U.S. 564 (1960) ; United Steelworkers v. Warrior \& Gulf Nav. Co., 363 U.S. 574 (1960); United Steelworkers v. Enterprise Wheel \& Car Corp., 363 U.S. 593 (1960).

161 NLRB v. Acme Industrial Co., 385 U.S. 432 (1967). See Blind Man's Buff, supra note *, at 578 .

162385 U.S. 421 (1967).

$163 I d$. at 426. Therefore, the Board's interpretation of the agreement in $C \& C$ $P l y w o o d$ "was in no way inconsistent with its previous recognition of arbitration as 'an instrument of national labor policy for composing contractual differences'." 
mental regulation of the terms of those agreements." 164 Moreover, "Congress was also concerned with the possibility of conflicting decisions that would result from placing all questions of contract interpretation before both the Board and the courts." ${ }^{165}$ Of course, where there is a collectively bargained arbitration provision and discovery is sought, there is a very real possibility of precisely that kind of conflict of decision between the Board's disclosure rulings under section 8 (a) (5) and the arbitrator's discovery decisions which are necessarily enforceable and reviewable in the courts under the protective provisions of rule 30 (b) of the Federal Rules of Civil Procedure. That possibility is absent, however, in a case like $C \& C$ Plywood because the only route to court is through interpretation of an arbitration provision, "since courts have no jurisdiction to enforce the union's statutory rights under $\S \S 8(\mathrm{a})(5)$ and (1)." 166

As the Supreme Court pointed out:

[I]n this case the Board has not construed a labor agreement to determine the extent of the contractual rights which were given the union by the employer. It has not imposed its own view of what the terms and conditions of the labor agreement should be. It has done no more than merely enforce a statutory right which Congress considered necessary to allow labor and management to get on with the process of reaching fair terms and conditions of employment-"to provide a means by which the agreement may be reached." The Board's interpretation went only so far as was necessary to determine that the union did not agree to give up these statutory safeguards. Thus, the Board, in necessarily construing a labor agreement to decide this unfair labor practice case has not exceeded the jurisdiction laid out for it by Congress. ${ }^{107}$

If arbitrators have the power to administer discovery in conjunction with the enforcement and protective jurisdiction of the courts, the Board will then be brought face to face with the inhibiting rationale expressed by the Court in that cautionary passage which is addressed to the Board as much as to the courts.

This is so despite the Court's decision in Acme Industrial that the statutory obligation to furnish information is enforceable by the Board even when a collectively bargained arbitration provision exists. The Court there rejected a dogmatic exclusion of Board jurisdiction "requiring the Board's deference to an arbitrator when construction 
and application of a labor agreement are in issue." 168 There undoubtedly will be cases, as observed elsewhere in this study, ${ }^{169}$ where the Board ought to be able to assert its jurisdiction despite the availability of arbitration. If, for instance, the information sought is not really vital and the cost of arbitration would be an undue burden to a small employer or local union, perhaps the Board's experienced investigative staff and more extended but cost-free procedures should be available for a party. Acme Industrial has enabled the Board to make that kind of particularized response to the necessities of each case. Such a rule reflects sound judicial administration on the part of the Court. But, as the Court realized in both $C \& C$ Plyzeod and Acme Industrial, it demands equally sound administration by the Board.

Acme Industrial has recognized the "arbitrator's greater institutional competency" ${ }^{170}$ in the court-arbitrator sequence established in the Steelworkers trilogy as compared with that of the Board. The role of the Board is complicated, in part, by its responsibility to administer the policies embodied in sections 8(a) (5), 8(d) and 10(a) of the National Labor Relations Act, and, in part, by the fact that arbitrators daily dispose of hundreds of grievances involving acts protected or prohibited by the act which (although this is atypical) may be brought to the Board despite their awards.

The Court has stated that the Board's 8(a) (5) order to disclose, "[f]ar from intruding upon the preserve of the arbitrator, . . . was in aid of the arbitral process;" the "discovery-type standard" applied by the Board was described as simply a "threshold determination concerning the potential relevance of the requested information" and "decided nothing about the merits of the Union's contractual claims." 171 But what of the employer's contractual claims? Is he not entitled to rely on a nonstatutory, contractual procedure for the prompt face-toface resolution of disputes like this one? As the Court reminds us in Acme Industrial, "the grievance procedure is . . . a part of the continuous collective bargaining process." ${ }^{172}$ As such, it is a negotiated benefit of considerable economic substance when set against the heavy burden in time and money imposed on a party compelled to respond to an NLRB charge.

There is no reason for the Board to be jealous of its prerogatives in this kind of case. C \& $C$ Plywood and Acme Industrial repeatedly emphasize the need for a flexible procedure of interaction between the

171 Id. at 437 n.3, quoting United Steelworkers v. Warrior \& Gulf Nav. Co., 363 U.S. 574, 581 (1960).

172385 U.S. at 439. 
Board and arbitration. The conclusion in Acme Industrial that the Board's 8(a) (5) order "was consistent both with the express terms of the Labor Act and with the national labor policy favoring arbitration . . ." will prove sound if the Board, instead of relying on the failure to invoke arbitration, commits run-of-the-mill contractual disclosure cases to arbitration as a first resort. Board procedures could then be utilized in those cases where governmental presence is needed as a catharsis or as a more effective discovery mechanism.

The relative flexibility available to the Board and to arbitrators can be seen by considering the prospects of a union in an Acme Industrial discovery situation. There the employer had moved out machinery and refused to answer reasonable inquiries by the union concerning its disposition. In order to get the withheld information the union was compelled either to go to arbitration or to seek the Board's intervention. It misguidedly chose the Board, running the risk that information which was vital to the union at the outset would be useless by the time the Board could be expected to get its disclosure order enforced many months later. Moreover, the federal circuit courts may (and often do) disagree with the Board's views, either on the significance of the facts before them or on the propriety of the substantive doctrines or remedial procedures adopted by the Board. ${ }^{173}$ Thus, if the employer does not voluntarily comply, the union will also have to run the reviewing gauntlet of the court before it can get the disclosure ordered by the Board a number of months earlier. Mr. Justice Stewart has posed the prospect that the "expense of arbitration might be placed upon the union only for it to learn that the machines had been relegated to the junk heap." 174 And what of the cost of delay to those employees who might be on layoff? Does federal law require them to submit to that greater expense despite their contractual claim to prompt disclosure? What the union eventually has obtained from the Supreme Court is enforcement of the Board's order some four years after it was needed. Now, at last, it will learn whether the employer's refusal to disclose has all along been simply a joke. The employer has known the answer all along; he has just refused to tell. That kind of refusal deserves an adequate response.

How would arbitration have been better suited to the union's needs? The arbitrator certainly could have ordered disclosure in a matter of weeks, thus relieving the union of the burden of waiting well

173 It should not make any difference whether a party has or has not invoked arbitration. Instead, the question is whether it makes good sense under the labor act to require the charging party to exhaust voluntarily accepted contractual procedures before allowing it to summon the other party involuntarily to a statutory proceeding at considerable cost in money and time and contrary to its bargain.

174385 U.S. at $438-39$. 
over a year for the Board to act. ${ }^{175}$ But assuming that the collective agreement contained a typical provision dividing the costs of an arbitration equally between the parties, what if the union cannot afford the expense of arbitration? In that unconscionable situation would it not be proper for the arbitrator to order the willfully withholding party to pay the cost incurred by the union in securing the information? A number of arbitrators would have no qualms about assessing that employer for the expenses, including attorney's fees and the direct costs of the arbitration, which were incurred by the union upon a finding that the refusal to disclose had violated the agreement. And even arbitrators who feel more constrained by the contractual provision for dividing the cost of arbitration still might be willing to assess damages against the withholder of information because of the egregious nature of the conduct. Most would want to be assured, of course, that the withholder was not somehow acting in good faith reliance on the absence, in the circumstances, of an obligation to disclose. ${ }^{176}$

Judicial enforcement under section 301 of this kind of assessment of costs linked to the disclosure award should present no problem. It is apparent that this employer has breached the condition of good faith compliance implicit in any contract, but particularly in a collective bargaining relationship between parties statutorily bound as a matter of national policy to bargain in good faith with each other. This is the kind of discretion in the fashioning of arbitral remedies, responsive to industrial reality, that the Court sought to insulate from judicial displacement in the Steetworkers trilogy. ${ }^{177}$ Such an order should be judicially enforceable under section 301 .

\section{Hoosier Cardinal and the Need for Uniformity}

In 1966, the Supreme Court held in $U A W$ v. Hoosier Cardinal Corp. ${ }^{178}$ that the statutory timeliness of a suit brought under section 301

175 See text accompanying note 27 supra.

176 The Board's doctrines are so clear and consistent over the years on the duty to disclose, that one may well question whether it would be reasonable to excuse a party for "good faith" ignorance on a matter so firmly imbedded in the law. After a11, the common sense of collective bargaining, even were it technically in good faith, would prompt disclosure without the need for contractual or statutory enforcement. Realistically, most cases of refusal to disclose involve parties motivated by antagonism. This author hastens to grant (indeed, to defend) the right of a collective bargainer to engage in adversary tactics; but, it is nonetheless true that the bargaining party who engages in such tactics can hardly cry surprise if he has to pay the cost for a tactical error in assessing how far he can properly press an adversary advantage under the contract.

177 See note 160 supra. The question how the availability of an arbitral remedy should affect the Board's disposition of refusals to disclose, upon the arbitral discovery order coupled with an assessment of costs against the withholder receiving judicial sanction, will be analyzed in the third and final article in this study.

178383 U.S. 696 (1966). 
shall be governed by the applicable state statute of limitations. The Court had earlier observed the need for uniformity, in Teamsters Local 174 v. Lucas Flour Co. ${ }^{179}$ foreseeing that "possible conflicting legal concepts might substantially impede the parties' willingness to agree to contract terms providing for final arbitral or judicial resolution of disputes." 180 But in Hoosier Cardinal the Court did not find varying state statutes of limitations a disturbing prospect, ${ }^{181}$ since lack of uniformity is "unlikely to frustrate in any important way the achievement of any significant goal of labor policy." 182

Our concern here is to assess the impact of Hoosier Cardinal on the fashioning of arbitral discovery under section 301. How is the Supreme Court apt to view one of the major devices-depositiondiscovery? In Hoosier Cardinal, the Court rejected any sterile exercise in affixing labels. It declined to inquire whether statutes of limitation are "substantive" or "procedural," "primary" or "remedial," in order to reach its decision. ${ }^{183}$ Instead, it approached the problem in terms of the need of collective bargaining administration for a uniform rule. The Court applied the usual rule that where federal statutes create a right of action without stating the time within which such action must be brought, state statutes of limitations should be applied. It rejected the view of the dissenters that Lincoln Mills required a uniform rule of limitation. ${ }^{184}$

The majority identified the need for uniformity as greatest "where its absence would threaten the smooth functioning of those consensual processes that federal labor law is chiefly designed to promote." 185 Since statutes of limitations "come into play only when these processes have already broken down," it saw no need for uniformity. ${ }^{186}$ This was simply not one of those "problems so vital to the implementation of federal labor policy that they will command a high degree of inventiveness from the courts." 187

Resort to discovery within the context of arbitration, however, cannot be regarded as a symptom of any breaking down of the "consensual processes that federal labor law is chiefly designed to promote." ${ }^{188}$ This is no more than the operation of the grievance

179369 U.S. 95 (1962).

180 Id. at 104.

181383 U.S. at 701.

182 Id. at 702 .

183 Id. at 703 n.4.

184 See id. at 701, 710.

$185 \mathrm{Id}$. at 702 .

186 Id.

187 Id. at 701.

188 Id. at 702 . 
procedure within an existing relationship. The administration of discovery (as distinguished from the application of a statute of limitations) in labor disputes arising under collective agreements is vitally important to both employers and unions. The absence of uniformity would indeed threaten consensuality. Imprudent granting or withholding of discovery procedures simply by the operation of a state statute could thoroughly disrupt an ongoing bargaining relationship.

One aspect of interaction between the Board and arbitration may be illustrated here. Abuse of arbitral discovery in a particular case may be challenged before the Board under sections $8(a)(5)$ or 8 (b) (3), as have other tactical abuses in the past, ${ }^{189}$ as a failure to bargain in good faith. If an arbitrator were to issue an improperly intrusive discovery order at the behest of a bad faith bargainer, the Board has ample precedent on which to ground its remedial reaction. ${ }^{190}$ Abuse of discovery, of course, is far more likely to be effectively remedied by the arbitrator himself. Failing that, the Board is available. More immediately, however, should the arbitrator's order initiate or perpetuate an abuse, resort should be available (under section 301) to the protection of Federal Rule $30(\mathrm{~b})$. There, a pattern of workable superintendency already exists - there is no need for judicial innovation. The federal judiciary have acquired considerable experience in administering discovery rules (as have many state courts) and have demonstrated their willingness and capacity to adapt to the Court's arbitration rationales which insulate arbitral discretion.

There is no reason to anticipate unusual difficulties in the interaction among courts, the Board, and arbitrators in administering a federal arbitral discovery remedy. Yet this inevitable interaction at least needs the uniformity of a federal remedy so that a welter of conflicting legal rules will not hamper or frustrate the intelligent resolution, responsive to collective bargaining realities, of arbitral discovery problems. Hoosier Cardinal amply supports the conclusion that uniformity will be required when it is needed to avoid the frustration of an important goal of labor policy. ${ }^{191}$ Disclosure in col-

189 See, e.g., NLRB v. Crompton-Highland Mills, Inc., 337 U.S. 217 (1949); NLRB v. Reed \& Prince Mfg. Co., 205 F.2d 131 (1st Cir.), cert. denied, 346 U.S. 887 (1953). But see NLRB v. Insurance Agents Int'l Union, 361 U.S. 477 (1960). In NLRB v. Katz, 369 U.S. 736, 747 (1962), the Court declared that "the Board is authorized to order the cessation of behavior which is in effect a refusal to negotiate, or which directly obstructs or inhibits the actual process of discussion, or which reflects a cast of mind against reaching agreement."

100 See, e.g., Raytheon Co., 140 N.L.R.B. 883 (1963) (Board declined to honor arbitrator's award because contractual issue did not encompass statutory issue of protected concerted action).

191 In considering the federal status of an arbitral discovery remedy in cases arising in or affecting interstate commerce, the doctrines unwound from Erie R. Co. v. Tompkins, 304 U.S. 64 (1938), are not apposite. We are not concerned with what law should be applied in diversity actions. Instead, we are concerned with the scope of 
lective bargaining, as the Court recognized in Acme Industrial and earlier cases, is most assuredly that kind of goal.

\section{Sources of Law for the Fashioning of Section 301 Arbitral Discovery}

The Supreme Court in Lincoln Mills made necessary the development of a body of federal law to be applied in actions under section 301 (a). The courts were directed to fashion this law from various existing legal rules-both state and federal. Obviously, if arbitral discovery is to be administered under the aegis of section 301, both federal and state discovery rules are ready-made sources for discovery procedure. Less obvious, perhaps, but nonetheless available and potentially quite useful as an innovative resource, is the United States Arbitration Act. ${ }^{192}$ We shall consider each in turn.

\section{The Protections Afforded by the Discovery Rules}

A major reason for acceptance of the Federal Rules is quite evidently the fact that the protections built into them as safeguards to undue intrusiveness are quite extensive. Thus rule 26(a) establishes that "Any party may take the testimony of any person, including a

congressional intent embodied in section 301. This is a matter of federal law since Liiccoln Mills. At the same time, however, two observations may be made in passing. First, Professor J. W. Moore, considering the import of Sibbach v. Wilson \& Co., 312 U.S. 1 (1941), has concluded that the discovery rules are "procedural" under the Erie doctrine so that "a federal court need not follow the discovery practice of the state in which the court is sitting even though the matter facing the Court is local in nature." 1A J. MOORE, Federal Practrce f0.317[3] (2d ed. 1965). See also Developments in the Law-Discovery, 74 HARv. L. Rev. 940, 1048 (1961) : A state's failure to provide particular discovery devices would not seem to be bound up with that state's definition of rights and obligations. Moreover, the existence of the Rules Enabling Act evidences a strong federal policy favoring a uniform system of federal procedure. To deny discovery when the Federal Rules would normally allow it is to attack the very heart of that system." Second, in assessing the constraints on the utilization by federal courts of the Federal Rules of Civil Procedure, the Court in Hanna v. Plumer, 380 U.S. 460 (1965), has held that the applicability of the procedures detailed in the Federal Rules shall not be barred by Erie in diversity cases. Categorizing as an "incorrect assumption," id. at 469-70, the notion that Erie "constitutes the appropriate test of the validity and therefore the applicability of a Federal Rule of Civil Procedure," the Court declared that

The Erie rule has never been invoked to void a Federal Rule. It is true that there have been cases where this Court has held applicable a state rule in the face of an argument that the situation was governed by one of the Federal Rules. But the holding of each such case was not that Erie commanded displacement of a Federal Rule by an inconsistent state rule, but rather that the scope of the Federal Rule was not as broad as the losing party urged, and therefore, there being no Federal Rule which covered the point in dispute, Erie commanded the enforcement of state law.

Id. at 470. See Mishkin, The Varionsness of "Federal Laze": Competence and Discretion in the Choice of National and State Rules for Decision, 105 U. PA. L. REv. 797 (1957), observing that a federal court will use state law either because it has to do so under Erie or because it is preferable to a national substantive rule. Professor Mishkin added, and Lincoln Mills confirmed, a third choice, that of state law because it is preferable, not as a "state law," but, by absorption, as "national labor policy."

1029 U.S.C. \$\$ 1-14 (1964). 
party, by deposition upon oral examination or written interrogatories for the purpose of discovery or for use as evidence in the action or for both purposes." Witnesses may be compelled by subpoena to attend, as provided in rule 45 , and shall be subject to direct and cross-examination under oath. Rule 26(b) states that it will not be a ground for an objection to the deposition "that the testimony will be inadmissible at the trial if the testimony sought appears reasonably calculated to lead to the discovery of admissible evidence." The deponent may be examined "regarding any matter, not privileged, which is relevant to the subject matter involved in the pending action."

Rule 30(a) provides for detailed notice to other parties to a pending action of the proposed taking of "the deposition of any person upon oral examination." Rule 30 (b) establishes comprehensive protective grounds for objections "upon notice and for good cause shown." The court in which the action is pending may order that no deposition shall be taken; or that it be taken at a certain place; or that it be taken only on written interrogatories; or that certain matters be excluded from inquiry; or that no one shall be present other than the parties and their counsel; or that the deposition, once taken, may be sealed and opened only upon order of the court; or that secret processes, developments, or research need not be disclosed; or that the parties shall simultaneously file information in sealed envelopes to be opened only as directed by the court.

The final clause of rule $30(\mathrm{~b})$ is the all-embracing provision that "the court may make any other order which justice requires to protect the party or witness from annoyance, embarrassment, or oppression." Under rule 30 (d) the court may also at any time during the taking of the deposition order the examination "to cease forthwith" or limit the scope and manner of its taking "upon a showing that the examination is being conducted in bad faith or in such manner as unreasonably to annoy, embarrass, or oppress the deponent or party." Furthermore, rule 31 (d) provides for the protection of persons whose depositions are being taken after service of written interrogatories by extending to them "upon good cause shown" any of the orders set forth in rule 30 (b) "which is appropriate and just."

Rule 33 establishes a system of written interrogatories to be served after commencement of an action upon and answered "separately and fully" in writing under oath and signed by "any adverse party," who "shall furnish such information as is available to the party." But objections may be served and heard on notice "at the earliest practicable time." Also, the number of interrogatories or sets of them to be served may be limited "as justice requires to protect the party from annoyance, 
expense, embarrassment, or oppression." The protective provisions of rule 30 (b) are also expressly made applicable to the party from whom answers to interrogatories are sought under rule 33 .

Rule 34 provides for the production of all kinds of documents "which constitute or contain evidence," or for entry upon premises to inspect or record things there, so long as either is within the scope of examination permitted by rule 26(b) ("regarding any matter, not privileged, which is relevant to the subject matter involved in the pending action").

Under rule 35, physical examinations may be ordered, but "only on motion for good cause shown." Rule 36 relates to obtaining admissions of the genuineness of documents.

Rule 37 arrays the contempt power of the district court against a party or deponent who refuses to be sworn or to answer any question or produce any document or undergo any physical examination after being ordered to do so by the court. It also establishes a range of other retaliatory orders by the court relating to assuming various incidents as proven or barred to be proven for purposes of the action. ${ }^{193}$

\section{The Federal Arbitration Act}

The United States Arbitration Act ${ }^{194}$ is the only general federal statute containing an integrated system of procedures for compulsory arbitration. Section 1 excludes from the Act "contracts of employment of seamen, railroad employees, or any other class of workers engaged in foreign or interstate commerce." Section 2 provides that "[a] written provision in . . . a contract evidencing a transaction involving commerce to settle by arbitration a controversy thereafter arising out of such contract or transaction . . . shall be valid, irrevocable, and enforceable ...." Section 7 empowers arbitrators to "summon in writing any person to attend before them or any of them as a witness and in a proper case to bring with him or them any book, record, document, or paper which may be deemed material as evidence in the case." Upon a refusal to obey a summons, the federal district court "upon petition" may compel attendance before the arbitrator through the sanction of its contempt power. Under section 10, an arbitral award may be vacated on certain grounds, including "(c) where the arbitrators were guilty of misconduct . . . in refusing to hear evidence pertinent and material to the controversy ...." 195

${ }_{193}$ See Professor Maurice Rosenberg's analysis of the problems encountered in regard to rule 37 in Rosenburg, Sanctions to Effectuate Pretrial Discovery, 59 CoLUM. L. REv. 480 (1958).

1949 U.S.C. $\$ \$ 1-14$ (1964).

1059 U.S.C. \& 10 (1964).

Railroad and aviation employees excluded from the Arbitration Act are covered by the provisions of the Railway Labor Act, 45 U.S.C. $\$ \$ 151-64$ (1964), section 7 of 
When the Act was passed in 1925, resort to labor arbitration was quite limited, the primary purpose of the Act undoubtedly being the enforcement of commercial arbitration agreements. The problem whether the new federal act should encompass grievance arbitration did not arise. Therefore, the task of interpreting the Arbitration Act does not require a determination whether there was an intended exclusion. Rather, the question presented is whether an adaptive or even a selective inclusion of arbitral discovery limited to labor arbitration is appropriate to the general purposes Congress sought to achieve in both the arbitration statute and section 301 of the Taft-Hartley Act.

The First Circuit Court of Appeals attempted just such an analysis in Local 205, IUE v. General Electric Co., ${ }^{196}$ in which it ordered enforcement of an arbitration provision in a collective bargaining agreement between GE and the union. The court concluded that it had jurisdiction under section 301(a) of the Taft-Hartley Act. But it felt constrained to resort to the Federal Arbitration Act for implementing enforcement machinery, thus rejecting the construction of section 301 later to be adopted by the majority in Lincoln Mills.

The court's reluctance to consider section 301 as the source of its enforcement power was principally based on its conclusion that a "comprehensive and consistent scheme" was "necessary for effective yet safeguarded arbitration." 197 That scheme only could come from legislative action. Since section 301 lacked "the procedural specifications needed for administration of the power to compel arbitration," 198 the court drew these from the Arbitration Act.

The court rejected GE's argument that the act did not apply to collective agreements, relying on the distinction made in $J$. I. Case Co. v. NLRB ${ }^{199}$ between a "contract of employment" and a collective agreement. The former is categorized as an "individual hiring contract" which "is subsidiary to the terms of the trade agreement." 200 As to the latter,

which establishes a procedure whereby the parties can select a board of arbitration with a tie-breaking neutral chairman. 45 U.S.C. \$157 (1964). Any controversy between a carrier and its employees can voluntarily be submitted to the board. Section 7 (h) requires that all testimony before a board of arbitration be taken under oath or affirmation, and empowers any member of the board to administer oaths or affirmation and to require attendance of witnesses and the production of documents "as may be deemed by the board of arbitration material to a just determination of the matters submitted to its arbitration. ..." The clerk of the appropriate federal district court "shall" issue the necessary subpoenas on the request of the board of arbitration or any one of its members. To compel compliance with a subpoena or "in the event of the contumacy of any witness appearing before the board of arbitration" the board "may invoke the aid of the United States courts. . ." 45 U.S.C. $\$ 157(\mathrm{~h})$.

196233 F.2d 85 (1st Cir. 1955), aff'd on other grounds, 353 U.S. 547 (1957).

$197233 \mathrm{~F} .2 \mathrm{~d}$ at 96.

198 Id. at 97.

199321 U.S. 332 (1944).

200 Id. at 336. 
Collective bargaining between employer and the representatives of a unit, usually a union, results in an accord as to terms which will govern hiring and work and pay in that unit. The result is not, however, a contract of employment except in rare cases; no one has a job by reason of it and no obligation to any individual ordinarily comes into existence from it alone. The negotiations between union and management result in what often has been called a trade agreement, rather than a contract of employment. ${ }^{201}$

Hence, the exclusion of individual contracts of hire from section 1 of the Arbitration Act had no reference to collective agreements.

Unfortunately, Judge Magruder's opinion has been overshadowed by the Supreme Court's invocation of Lincoln Mills in affirming General Electric. ${ }^{202}$ In the former, the Court summoned a "range of judicial inventiveness" to be "determined by the nature of the problem," ${ }^{203}$ but, oddly, did not also apply the creative analysis suggested by Judge Magruder. Instead, the Court's brief opinion in General Electric disposed of Judge Magruder's reasoning in an enigmatic way which by no means ruled out the possibility of enforcing collective agreements under the Arbitration Act. The Court simply observed that, "We follow in part a different path than the Court of Appeals, though we reach the same result. As indicated in our opinion in . . . Lincoln Mills . . . we think that $\S 301$ (a) furnishes a body of federal substantive law for the enforcement of collective bargaining agreements in industries in commerce or affecting commerce. . . ."204 The suggestion would seem to be not that the path of the court of appeals led in the wrong direction, but that it was unnecessary to use it to reach the desired goal. Under the Court's reasoning, the arbitration statute might still be available as a means of implementing the national labor policy, if Judge Magruder's analysis of the crucial distinction between a contract of employment and a collective agreement is valid, as it clearly seems to be.

Additional support for the view that Congress intended the federal Arbitration Act to be selectively available in labor arbitrations is derived from section 302 of the Labor-Management Relations Act. ${ }^{205}$ In that section Congress placed certain restrictions upon employer

201 Id. at 334-35.

202353 U.S. 547, 548 (1957).

203353 U.S. 448,457 (1957).

204353 U.S. at 548.

205 LMRA \$ 302, 29 U.S.C. \$ 186 (1964).

$I$ am indebted to a former student and now experienced labor counsel, Jerry $J$. Williams, for calling this $\$ 302$ analysis to my attention as corroborating the basic thesis that the Federal Arbitration Act remains a usable resource for Lincoln Mills innovation. 
payments to employee representatives. Section 302(c), however, details certain exceptions to the general bar on such payments, as, for example, in the case of payments to trust funds for employees so long as fund administrators are evenly apportioned between employer and employee representatives. In the event of a deadlock in the administration of the funds and failure to designate "an impartial umpire to decide such dispute," section 302 (c) (5)(B) provides that the umpire "shall, on petition of either group, be appointed by the district court of the United States . . . ." The umpire, of course, is an arbitrator and is typically so regarded and designated by parties incorporating trust fund provisions in collective agreements. The words "on petition" are words of art which correspond to the provision in section 4 of the Arbitration Act for enforcement by "petition" to an appropriate federal court. By combining section 302(c)(5)(B) of the LiMRA with section 4 of the Arbitration Act, Congress has thus provided for the enforcement of arbitration by means of the expeditious petition procedure rather than through the more cumbersome civil action processes. $^{206}$

These indications of the availability of the arbitration statute are by no means negated by the Supreme Court's treatment of Judge Magruder's reasoning in General Electric. Rather, the Court's attitude toward the Arbitration Act appeared simply to be, "who needs it?" 207 Whatever may have been the reason for the Court's omission of any mention of the Arbitration Act in its opinion in Lincoln Mills, the observable consequence of the Court's silence on the import of the Act is to preserve its availability as a resource for formulating remedies mandated in that case.

How can the Arbitration Act help fashion a more workable means of carrying out national labor policy? It need not be regarded as a source of authority in and of itself. The lever is Lincoln Mills; the fulcrum is section 301. The Arbitration Act is simply one resource among several from which techniques may be derived for use in the labor area. In this regard, section 7 of the Arbitration Act is of particular importance. There the power is created to summon wit-

200 The petition procedure is far more expeditious than that of rule 3 which provides that a civil action is commenced by filing a "complaint" with the court. The former merely requires notice of motion; the petition is then heard and disposed of by the district court with little consumption of time.

207 Indeed, it made some judicial and administrative sense in that case to use the four corners of section 301 (a) as the locus of federal rights. In the fashioning of remedies, the Arbitration Act could not afford nearly the same degree of flexibility or responsiveness to changed conditions if it were regarded as the sole and entire source of enforceability, as it could if it were merely one among several resources for the shaping of national labor policy. Moreover, it should be realized that the Arbitration Act does not confer non-diversity jurisdiction irrespective of the amount in controversy as does section $301(a)$. 
nesses and produce documents "which may be deemed material as evidence in the case." Although the Act does not expressly empower arbitrators to administer oaths, that power is necessarily implied by the authorization to summon a "witness"-i.e., "one who has been sworn according to law and deposes as to his knowledge of facts in issue upon trial of a case. . . ." 208

Although the limitation of the subpoena power in section 7 of the Arbitration Act to items "material as evidence" would appear to preclude arbitral discovery orders of the scope embodied in the Federal Rules of Civil Procedure, the legal concept of materiality can hardly be said to be one of precise dimension. Furthermore, section 10 puts pressure on the arbitrator to resolve doubts of materiality in favor of admissibility by categorizing a refusal to hear material evidence as misconduct warranting vacation of an arbitral award. A further problem arises, however. Since there is no provision in the Act for the taking of depositions, it would seem to follow that the power to order depositions of persons unable to attend is implicit in the power to summon persons to attend as witnesses. Were that reasoning as to the administering of depositions to prevail it might warrant the conclusion that depositions are limited to the same extent as is the subpoena duces tecum, that is, to use as evidence material to the proceeding. Here the Federal Rules of Civil Procedure come to our assistance. Rule 81 (a) (3), referring expressly to the Arbitration Act and the Railway Labor Act, makes the rules applicable "only to the extent that matters of procedure are not provided for in those statutes." From the context, it appears that rule 81 (a) (3) refers only to express procedural provisions in the acts and not to those which might arguably be deduced from them. If so, restrictions on the use of subpoenas will not apply to depositions (as to which the Arbitration Act is totally silent).

There is no more direct a reference to the administration of oaths in the Federal Rules than there is in the Arbitration Act. Rule 45(a) details how subpoenas may be issued to command persons "to give testimony," but does not use the word "witness." By contrast, rule 45 (e), referring more precisely to subpoenas for attendance "at a hearing or trial," does use the word "witness." Hence, the power to administer oaths is necessarily implied under both rule 45 and section 7 of the Arbitration Act.

However, there remains still another possible obstacle to arbitral discovery. In commercial arbitration it has been held that prehearing discovery procedures not provided for in the federal arbitration statute 
are not available through the Federal Rules. The district court in Commercial Solvents Corp. v. Louisiana Liquid Fertilizer Co. ${ }^{209}$ reasoned that rule 81 (a) (3) is restricted to "proceedings under" the arbitration statute, and that prehearing discovery is not a proceeding "under" the statute as is, for instance, a motion to stay an action pending arbitration or to confirm an award. It also expressed the view that, by voluntarily agreeing to arbitration as the mode of settling disputes, the parties elected to avail themselves of procedures peculiar to the arbitral process rather than those to be found in judicial proceedings. The court, therefore, remitted the parties to the commercial arbitration rules of the American Arbitration Association which they had incorporated in their agreement. ${ }^{210}$ Certainly this is an overly restrictive reading of rule 81 (a) (3). Moreover, to conclude that the parties cannot have prehearing discovery because they opted for arbitration instead of adjudication is to beg the question at issue, which is, shall prehearing discovery be deemed to be as freely available in arbitration as it is in adjudication? A more convincing analysis was advanced by a district court sitting in admiralty, which indicated, "[i]t may be that there is a limited area for application of discovery procedures to proceedings under Title 9... . But I do not think that Rule 81(a) (3) is designed to allow judicially imposed and controlled discovery as to the merits of a controversy which will be referred to arbitration under 9 U.S.C. $\S 4$, except, perhaps, upon a showing of true necessity because of an exceptional situation. . . ." 211 It is possible, however, to establish a discovery procedure for labor arbitration which would not require judicial control of discovery and which would not place judges and arbitrators in functional conflict. First-instance decisions could be allocated to the arbitrators and Steelworkers trilogy-type review to the judges. There would then be no reason to fear judicial intervention contrary to the intent of the parties who have opted for arbitration in lieu of adjudication. That, of course, is the remedial structure recommended in this study.

The availability of arbitral discovery is a necessary corollary of labor arbitration in aid of collective bargaining. It is arguable that Congress, which intended that a federal common law be evolved to govern the enforceability of arbitration provisions, logically also intended that this remedial adjunct be available. The courts should not hold back, therefore, from completing the structure as needs become manifest with the passage of time and experience. There is a substantial and inescapable innovative element involved in any choice of

211 Penn Tanker Co. v. C.H.Z. Rolimpex, 199 F.Supp. 716, 718 (S.D.N.Y. 1961). 
remedy made by the courts under the aegis of Lincoln Mills. The important thing is that the choice be soundly based in the realities of collective bargaining and in the national labor policy designed to foster it.

\section{IV}

\section{Conclusion}

The major legal hypothesis tested in these pages is that section 301 of the Taft-Hartley Act, as interpreted by the Supreme Court in Lincoln Mills and subsequent cases, has established the availability of the United States Arbitration Act and the Federal Rules of Civil Procedure, as needed, to enable the fashioning of remedies for use in the arbitration of labor disputes affecting interstate commerce. A subsidiary proposition is that federal law, so construed, enables the existence of federal arbitral discovery remedies.

In Lincoln Mills the Court summoned federal and state courts to fashion doctrines that will best effectuate the federal policy to encourage arbitration of labor disputes. State law may also be utilized, but it will then "be absorbed as federal law and will not be an independent source of private rights." 212 Furthermore, the Court has since declared that the " 'procedural questions' which grow out of the dispute and bear on its final disposition should be left to the arbitrator." 213 Finally, the Court in Acme Industrial, in deciding how to allocate jurisdiction among the Board, the courts, and arbitrators to administer discovery procedures incident to the operation of collectively bargained grievance procedures, wisely elected to defer to the Board so that it might initially formulate policy, thereby making possible the fashioning of a realistic sequence of interaction between Board, arbitrator, and courts. But the Supreme Court was also careful to emphasize that it was not eroding the policies it had enunciated in the Steelworkers trilogy. It explicitly reaffirmed its conclusion of "the arbitrator's greater institutional competency" compared to the courts'. And it clearly implied that the Board should be circumspect about intrusions into the realm of contractual interpretation reserved by the bargainers for arbitration.

The development of viable arbitral discovery procedures is bound to be complex. It will be more effectively accomplished in the traditional common law manner than by statutory or general rule-making fiat. This is especially true in light of the fact that these procedures will have to evolve in response to both a variety of dynamic collective bargaining NOW-problems and to the possible modes of interaction 
among arbitrators, the Board, and state and federal courts. This complexity is no excuse for recoiling from the task, but it demands great care in gauging the proper dimensions of arbitral discovery, as well as prudence in the fashioning of adequate safeguards to curb the overzealous and to calm the overanxious in collective bargaining discovery situations. This kind of prudence is part of the "institutional competency" of arbitrators rather than courts.

The fact that discovery situations are (and should remain) unusual in labor arbitrations warrants a design for arbitral discovery of some procedural complexity. It is not a remedy to which either the blithe spirit or the maliciously bent ought to have ready access. Resistors must be built into the circuit. At the same time, precautions are also warranted since arbitral discovery will often be administered by arbitrators not accustomed to these legal devices, and will be resorted to by bargainers more mindful of next year's negotiations than next month's grievance arbitration. There is a discovery rule which cannot too often be repeated and which should be the arbitrator's prime procedural discovery guide. It is well expressed in the words of Chief Justice Traynor of the California Supreme Court: "[T]o secure discovery, there must be a showing of more than a wish for the benefit of all the information in the adversary's files." 214 There must be a showing both of "need and specificity." 215 The "why," the "what," and the "how" must be stated as precisely as possible.

We saw in the first article in this study that there is a recurrent need for a discovery remedy in the routine operation of grievance procedures, prior to and during the course of arbitrations. We have now found that legitimate concerns at the prospect of arbitral discovery could be satisfied so as to enable resort to the remedy when needed, consonant with sound collective bargaining theory and practice. And we have now also seen that the relevant federal statutory and judicial policies support the arbitral discovery remedy.

To conclude on a somewhat ironic note, if these propositions are valid, an arbitrator who refuses a discovery order in circumstances of demonstrated need may actually find his award vacated. An almost universal ground for vacating an arbitrator's award, one of the very few, is that expressed in the words of section 10 (c) of the United States Arbitration Act: "Where the arbitrators were guilty of misconduct in refusing . . . to hear evidence pertinent and material to the controversy." 210 Indeed, it has already been stated by the Second

214 Shively v. Stewart, 65 Cal.2d 475, 482, 421 P.2d 65, 69, 55 Cal. Rptr. 217, 221 (1967).

215 Id.

2169 U.S.C. $\$ 10(\mathrm{c})(1964)$. 
Circuit that under that section a refusal of arbitrators, on request, to order production of books and records, "material" in the court's view, may be ground for setting aside a subsequent award..$^{217}$

In the third and final article of our study we shall turn to a consideration of the Labor Board's disposition of refusal-to-disclose cases and to the framing of a workable sequence of responsibility for arbitral discovery, geared to the respective institutional capacities of the Labor Board, the courts, and the arbitrators.

217 Hyman v. Pottberg's Ex'rs, 101 F.2d 262, 265 (2d Cir. 1939).

Compare Harvey Aluminum, Inc. v. United Steelworkers, 263 F. Supp. 488, 495 (C.D. Cal. 1967), where the court vacated an award because the arbitrator refused to accept the testimony of an employer's witness and remanded to the arbitrator for the taking of testimony "which the court finds to be pertinent and material," with Atlas Floor Covering v. Crescent House and Garden, Inc., 166 Cal. App. 2d 211, 333 P.2d 194 (1958), where the court held it was not reversible error for the arbitrator to refuse to issue a subpoena duces tecum since the parties had agreed to be bound by AAA rules expressly providing that arbitrators shall be the judges of materiality and relevance. 